\title{
Assurance on CSR reports: impact on the credibility perceptions of non-financial information by bank directors
}

\author{
Reiner Quick
}

Department of Accounting and Auditing, Darmstadt University of Technology, Darmstadt, Germany, and

Petra Inwinkl

Department of Financial Enterprise Management, Institute of Management Science, Vienna University of Technology, Vienna, Austria

\begin{abstract}
Purpose - This paper aims to clarify whether assurance on non-financial corporate social responsibility (CSR) reports impacts the perceptions and decisions of banks as capital providers. The authors investigate the effects of the type of assurance provider and the level of assurance provided on decisions by banks to grant credit, make their own personal investments or recommend share purchases to their customers. The study aims to expand the domain of assurance on CSR reports (CSRR) by taking up a call by Cohen and Simnett (2015), who ask for behavioral research on how non-financial report's intended users interpret and react to assurance.

Design/methodology/approach - The paper is based on an experiment case on a fictitious company with a $2 \times 2+1$ between-subjects design. To overcome concerns regarding external validity and to prove results in a real-world setting, the authors selected German bank directors as subjects due to the extremely high relevance of banks to the German economy. The authors investigated the perceptions of 69 bank directors and analyzed the influence of CSR assurance on their decisions.

Findings - The findings suggest that assurance positively influences confidence in CSRR and that, consequently, bankers are more likely to make favorable decisions toward the reporting companies, such as approving applications for credit, investing themselves in the company or recommending the purchase of shares to their clients. These effects are stronger when an accounting firm provides the assurance and when the assurance level is reasonable rather than limited.

Research limitations/implications - The arguments presented are, strictly speaking, limited to the case in the experiment and the views held by the bank directors at the time the authors sent out the questionnaires. Moreover, the cell sizes are quite small. Nevertheless, the authors were able to find highly significant results.

Practical implications - The main implication of the paper is that the purchase of CSRR assurance services has a positive effect on bank directors' perceptions and decisions. They favor the provision of such services by accounting firms and they prefer a reasonable assurance level. Thus, it can be concluded that bank directors perceive quality differences between assurance providers, are able to recognize the difference between reasonable and limited assurance and that the related information is relevant for their decisions.
\end{abstract}

(C) Reiner Quick and Petra Inwinkl. Published by Emerald Publishing Limited. This article is published under the Creative Commons Attribution (CC BY 4.0) licence. Anyone may reproduce, distribute, translate and create derivative works of this article (for both commercial and noncommercial purposes), subject to full attribution to the original publication and authors. The full terms of this licence may be seen at http://creativecommons.org/licences/by/4.0/legalcode
Received 29 October 2019 Revised 25 January 2020 7 April 2020 Accepted 21 April 2020 
MEDAR 28,5
Originality/value - This paper fulfils an identified need to study the influence of CSRR assurance on decisions by bank directors. The observation of a high decisions-usefulness of CSRR assurance suggests that regulators should consider mandating some form of assurance on non-financial reports throughout the EU member states.

Keywords Assurance level, Assurance provision, Bank directors, Corporate social responsibility reports

Paper type Research paper

\section{Introduction}

Nowadays, companies are being held to account for the social and environmental consequences of their activities, and, as a result, corporate social responsibility (CSR) has become an inescapable priority for business leaders (Porter and Kramer, 2006). Research on the influence of CSR over a firm's economic output shows some support for a positive impact through positive correlations between CSR reports (CSRR) and access to finance (Cheng et al., 2014), lower equity capital costs (Dhaliwal et al., 2011) and lower banks loan costs (Goss and Roberts, 2011). The European Union (EU) has also recognized the need for managing change toward a sustainable global economy and has established minimum legal requirements for non-financial reporting, thereby mandates CSR reporting, and in doing so raises the profile of CSR reporting within organizations. EU Directive 2014/95 requires public-interest entities with more than 500 employees during a given financial year to disclose a non-financial statement. At a minimum, this statement must provide information on specific environmental, social, employee, human rights, anti-corruption and bribery matters (European Parliament and Council of the European Union, 2014).

Two aspects of the EU Directive 2014/95 are particularly interesting in terms of how stakeholders perceive the credibility of the non-financial information a company presents. Credibility requires that the reports are reliable, i.e. they must be prepared in a way that they can be subject to examination and balanced, i.e. they must reflect all material positive and negative aspects (Farooq and de Villiers, 2020). First, it only mandates that an auditor must check to ensure that the required non-financial statement has been provided. Second, member states may, at their discretion, mandate that an independent assurer verifies the information provided within the non-financial statement. Such as most member states, Germany implemented EU Directive 2014/95 on April 11, 2017, via the CSR-Richtlinie-Umsetzungsgesetz (Law on the Implementation of the EU Directive 2014/95). In its implementation, Germany did not mandate independent assurance; thus, providing external verification of the non-financial information disclosed is entirely voluntary (Deutscher Bundestag, 2017). However, externally verifying this information has the potential to increase its credibility, augment the social legitimacy or organizations and generate greater confidence among stakeholders (Power, 1997; Gilbert and Rasche, 2007; Boiral, 2013). This seems especially to be true in a scenario with mandatory CSR reporting in which organizations are more likely to demand external assurance of their CSRR (Ackers and Eccles, 2015). Further, stakeholders are becoming increasingly aware that some of the non-financial aspects of a company can be highly relevant to its financial performance and to the creation of value (Reimsbach et al., 2018). Demand for greater disclosure of these issues is therefore growing, and G250 companies seem to be responding in kind. According to a recent report by KPMG, 67\% of G250 companies have sought to independently assure their CSR data (KPMG, 2017). This resonates well with the question of whether such assurance is beneficial to a company's stakeholders. In this context, the perceptions of bankers as capital providers are of interest. Do they also find external assurance beneficial? Then, if so, how do these benefits manifest? 
In this paper, we examine whether assurance over CSRR impacts the perceptions and decisions of banks as capital providers. More specifically, we investigate the effects of the type of assurance provider and the level of assurance provided on decisions by banks to grant credit, make their own personal investments or recommend share purchases to their customers. In the German environmental setting, debt financing is more important than in Anglo-Saxon countries (Detzer, 2014), banks are important providers of debt but also of equity capital, and they have insights and influence via representatives on supervisory boards. We apply an experimental research design. In an experiment, independent variables are manipulated and dependent variables are measured; any extraneous variables are controlled. Thus, the results allow the researcher to claim causation. Participants do not know the research objectives and the researchers have little contact with them and cannot impose their own opinions. As a consequence, the data are more valid and less biased. Moreover, an experiment can be performed when archival data is not available. In undertaking this research, we are also taking up a call by Cohen and Simnett (2015) who ask for behavioral research on how a non-financial report's intended users interpret and react to assurance. Bank directors were chosen as our subjects of study because bankers reflect different interest groups, including creditors, investment consultants and private and professional investors.

In general, our findings support our hypotheses in that bank directors rely more on a CSRR that has been assured than one that has not; and that assured CSRR increase the likelihood of credit approvals, investment recommendations and their own investment decisions. Additionally, perceptions toward CSRR assurance differ by the type of assurance provider and the level of assurance provided as do the decisions made as a consequence. Assurance provided by an accounting firm has a stronger positive impact than assurance from the technical control board and more importance is attached to reasonable assurance than limited assurance, which reduces the risk of engagement to the lowest level of acceptable risk (ISAE 3000.12).

Despite the voracity of the discussion by various national and supranational organizations over whether CSRR assurance should be mandatory or voluntary, research is scarce. Only a handful of experimental studies on the effects of assuring CSRR have been conducted in the USA, Australia and the UK, whereas there is a lack of experimental findings from Continental European countries. There, only some archival research has been done, but mainly in Spain. As noted by Abernathy et al. (2017), the influence of the type of provider, the level of assurance provided and the perceptions of capital providers are all under-researched areas. Cohen and Simnett (2015, p. 71) describe it as a "relatively underresearched but potentially rich and fruitful area for future research.” We respond to this statement by investigating the decision-usefulness of CSRR assurance for a sample of German bank directors. In particular, we show the influence of CSRR assurance on decisions by bank directors after the implementation of the EU Directive 2014/95.

Bank directors are typically highly knowledgeable people and notoriously difficult to attract for research studies. As subjects of study, bank directors are of particular relevance as creditors, investors and financial intermediaries. Thus, our results provide insights into the impact of CSRR assurance on the decisions of banks as capital providers. Prior experimental research did not investigate the impact of CSRR assurance on the perceptions and decisions of bank directors and highly knowledgeable subjects may react differently on assured reports. To the best of our knowledge, this is the first study to try and generate new insights into the way assurance on CSRR is perceived as the adoption of the EU Directive 2014/95 which harmonized CSRR within the EU, made it mandatory, and thus, changed the environmental setting. Furthermore, recent scandals may have eroded trust in assurance 
MEDAR 28,5 providers and this potentially reduces the impact of assurance on credibility. In addition, this research contributes to the literature on the theory of professions and the theory of source credibility by using both in a novel context. The findings of this study should be of interest to national and supranational regulators and standard setters, and in particular to their deliberations on whether or not to make CSRR assurance mandatory.

The paper proceeds as follows. Section 2 provides some background information, an overview of prior research and the hypotheses. Section 3 describe our experimental case and the subjects participating in the study, followed by the empirical results. Finally, Section 4 summarizes the main findings, discusses their implications, points to the study's limitations and identifies areas for future research.

\section{Background, prior research and development of hypotheses \\ 2.1 Assurance provision}

Legitimacy and signaling theory may explain why some stakeholders positively perceive the voluntary assurance of CSRR. "[I]t is probable that legitimacy theory is the most widely used theory to explain environmental and social disclosures" (Campbell et al., 2003, p. 559). Legitimacy theory explains that companies assume an implicit social contract between themselves and society, which, in turn, encourages them to comply with certain norms and values (Cuganesan et al., 2010).

Thus, legitimacy theory has come to stress how corporate managers react to community expectations (Deegan, 2019): managers will implement a set of legitimating strategies and firms will engage in CSR reporting because the company needs to legitimate its activities (Fernando and Lawrence, 2014; Patten, 2019). The set of legitimating strategies usually consists of regulative, cultural and normative elements that essentially provide management with a corporate governance instrument. Complying with the law has been referred to as "pragmatic legitimacy," whereas complying with the prevailing cultural expectations of the time has been linked to what is called "cognitive legitimacy" while complying with the normative expectations of a particular corporate environment has been claimed as a way of generating "moral legitimacy" (Deegan, 2019). Externally-available company disclosures, such as those found in CSRR, reflect a pragmatic approach to legitimacy as the disclosures satisfy the perceived needs of specific stakeholder groups (e.g. shareholders or employees) (Dumay et al., 2015). Managers are aware of this pragmatic approach to legitimacy and their decision to assure a CSRR can be seen as a corporate governance instrument for legitimizing aspects of a company's sustainability (Faisal et al., 2012; Velte and Stawinoga, 2017). However, they know that, over the long-term, they cannot afford to ignore any of these three forms of legitimacy (Deegan, 2019).

Obtaining third-party assurance can be a valuable tool for addressing concerns regarding the credibility of information provided in CSRR (Cho et al., 2014; Simnett et al., 2009). Hence, an important aspect of CSRR assurance lies in its ability to enhance the credibility of the reported information and thereby legitimate the CSR efforts of the firm (Simnett et al., 2009; Kolk and Perego, 2010). In this context, CSRR assurance is the beginning of a process that allows a company to assess its performance in relation to the expectations of society (Deegan, 2002). In terms of legitimacy theory, CSRR assurance can be viewed as a managerial device that directs various social pressures away from a company.

While many adopt legitimacy theory as a theoretical perspective for explaining why stakeholders perceive voluntary CSRR assurance positively, some theorists consider that legitimacy is influenced by the actions set by the management to signal the credibility of a company's reported information. Signaling theory views firms as pools of information that stakeholders are not aware of, and reporting as a way for firms to reduce information 
asymmetry (Connelly et al., 2011). While CSRR can signal some of these hidden characteristics, CSRR assurance can provide insights into the actions of managers, signaling the credibility of the reported information (Ruhnke and Gabriel, 2013; Alon and Vidovic, 2015). In using signaling theory to examine stakeholder confidence in the credibility of CSRR, some studies postulate that there could be possible competitive advantages for a company, such as a better access to finance or reduced cost of capital (Dhaliwal et al., 2011; Cheng et al., 2014; Braam and Peeters, 2018).

In fact, archival research that finds and does not find support for the benefits of external CSRR assurance is relatively evenly divided. In the positively correlated camp, an empirical study conducted by Moroney et al. (2012) using data from Australian listed companies shows that the quality of voluntary environmental disclosures is significantly greater in assured reports than in non-assured reports. Using CSR restatements as a proxy with a worldwide sample, Ballou et al. (2018) demonstrate that CSRR assurance improves CSRR quality. Likewise, Michelon et al. (2019) find that voluntary assurance of sustainability reports is associated with increased sustainability restatements. Birkey et al. (2016) reveal that assurance on CSRR is positively associated with environmental reputation for US firms'. From a sample of international companies, Martínez-Ferrero and García-Sánchez (2017) found lower costs of equity capital for companies that assure their sustainability reports. Similarly, Casey and Grenier (2015) revealed that CSRR assurance in the USA is associated with a lower cost of capital along with lower forecast errors and dispersion. For the world's largest listed firms, assured sustainability reporting leads to more accurate analysts' forecasts (Cuadrado-Bellesteros et al., 2017).

Conversely, other research finds little to no upside from CSRR assurance. With an international sample, Alon and Vidovic (2015) estimated the effect of third-party assurance of firm sustainability reports on their reputation for sustainability using covariance-based structural equation modeling (SEM) path analysis. They did not find a statistically significant impact, concluding that external stakeholders do not incorporate such assurance into their evaluation of firm sustainability reputations. In US companies, Cho et al. (2014) failed to identify a significant association between CSRR assurance and firm value. In Italian listed firms, Fazzini and Dal Maso (2016) do not find an increase in the market value linked to the external assurance of environmental disclosures. Then, in Spanish listed companies, García-Benau et al. (2013) conclude that changes in the CSRR assurance strategy of companies does not have a significant impact on their assets or equity returns, the market to book ratio and Tobin's Q. Findings from Gietl et al. (2013) for STOXX Europe 600 firms indicate that the issuing of external assured CSRR could even be negatively related to firm value, according to Tobin's $\mathrm{Q}$.

Experimental studies complement these archival findings, but, this time, the results form a consistent chorus of support for CSRR assurance as an advantageous undertaking. Evidence by Hodge et al. (2009) reveals that assuring a sustainability report increases the perceived credibility of the environmental and social information it holds. The participants in this study were MBA students enrolled at Australian universities serving as proxies for typical sustainability report users. In a behavioral experiment, Pflugrath et al. (2011) examined whether financial analysts from Australia, the USA and the UK perceived a difference in the credibility of CSRR depending on whether they were assured. The results show that the credibility of a CSRR to be greater when assured than when not.

Coram et al. (2009) performed an experiment with chartered accountants and members of the Securities Institute of Australia as proxies for "sophisticated financial statement users." Their findings indicate that an assured report only has a significant effect on stock price estimates when the disclosed non-financial indicators are positive. Yet, in a similar 
MEDAR 28,5 experimental study in the USA, Brown-Liburd and Zamora (2015) find that CSR information is only value relevant if it has been assured and that assurance has a positive impact on the investors' stock price assessments.

Results from Australia by Cheng et al. (2015) highlight that assurance can increase an investor's willingness to invest if the environmental, social and governance indicators are highly relevant to a company's strategy. Findings from Shen et al. (2017) in the Chinese context indicate that CSRR assurance impacts decision-making by non-professional investors and can increase an investor's willingness to invest and also that this effect is greater when CSR disclosures are positive than when they are negative. Note that the "nonprofessional investors" in this study were postgraduate students enrolled in a Masters of Finance program. Research by Reimsbach et al. (2018) in Germany shows that assuring sustainability information positively affects the evaluations of a firm's sustainability performance by professional analysts and fund managers and increases the attractiveness of the investment.

Overall, the archival research findings are mixed, but, in contrast, almost all experimental studies reveal CSRR assurance has a positive impact, at least under certain conditions. Companies may opt for voluntary CSRR assurance to legitimize the company and to prove its commitment to sustainability or to signal credibility of its disclosed nonfinancial information. Against this theoretical backdrop, we ask the research question: Does assurance impact the perceptions held by bank directors of whether reported CSR information is credible? Drawing on both legitimacy and signaling theory, as well as based on previous archival and experimental research, we anticipate that CSRR assurance will have a positive effect on bank directors' decision-making. Hence, we formulate our first hypothesis as follows:

H1. CSRR assurance will have a positive impact on a bank director's decisions.

\subsection{Type of assurance provider}

Differences in the way bank directors perceive the assurances given by different types of providers may be grounded in the theory of professions. Professions and professionalization have increasingly become a key facet of socio-economic development in the modern world (Brock et al., 2014). Accordingly, the theory of professions provides guidance in the core characteristics of the dynamics of professional groups. For instance, formal education and training is an important characteristic of many professions and, usually, learning from the required systematic knowledge base is controlled by a professional body. Often, some form of certification is attached to the training that serves as an entry permit to future employment in the field. Thus, "the profession" becomes recognized as a distinct and credible authority within its domain.

Another distinguishing trait of a profession is that its practitioners frequently work in accordance with ethical codes, i.e. specific norms, values and expectations concerning personal conduct. Professional standards of practice are typically agreed upon and maintained through widely-recognized professional associations. These professional associations also generally take responsibility for evaluating and disciplining the conduct of the field's practitioners.

A final feature of a profession is that it exists because it serves a function to society. Implicit in this characteristic is that its professionals should apply their knowledge and skills in an altruistic and ethical manner and enjoy public trust in exchange (Freidson, 1986; Abbott, 1988; Freidson, 1989; Larson, 1990; Macdonald, 1995; Sullivan, 2005; Saks, 2012; Ackroyd, 2016). However, professions are also commonly described in terms of the way 
they, perhaps unfairly, exercise their power or pursue their own elite self-interests - say, by seeking to create a monopoly for their services or restricting practitioner numbers to maintain fee levels or social standing (Larson, 1977).

By all these criteria (e.g. formal education and training controlled by a professional body, certification, work in accordance with ethical codes, fulfillment of a societal function), auditors belong to a profession.

Many archival studies have explored the link between the type of provider and the (perceived) quality of assurance provided. In a study of US firms, Birkey et al. (2016) find that outside assurance enhances a firm's environmental reputation regardless of the assurer type. Moreover, studies by Perego and Kolk (2012) and Ballou et al. (2018) indicate that the quality of assurance is highly dependent on the type of provider. In contrast, Moroney et al. (2012) do not find an impact of the assurance provider on the quality of voluntary environmental disclosures. Peters and Romi (2015) provide evidence that, when provided by professional accountants, the value-relevance of sustainability assurance increases over time. In a later sample period (2008-2010), they also find a significant positive association between such assurance and the market valuation of equity. Casey and Grenier (2015) show that, in the US CSRR assurance market, reductions in the cost of equity capital and analyst forecast dispersion are significantly higher when CSRR assurance is provided by an accounting firm. Similarly, findings from Martínez-Ferrero and García-Sánchez (2017) indicate the cost of equity capital is much lower when assurance is provided by a Big 4 accounting firm versus an engineering or consultancy firm. Research by CuadradoBellesteros et al. (2017) reveals that analysts produce more accurate forecasts from sustainability reports that have been assured by a Big 4 accounting firm than other providers. Similarly, Martínez-Ferrero and García-Sánchez (2018) show that the probability of detecting material errors and omissions in a sustainability report is higher if it is verified by a Big 4 accounting firm and by an industry expert as an assurance practitioner. MartínezFerrero and García-Sánchez (2018) also find an impact of the brand reputation and industry specialization of assurance providers on the level of assurance.

The conclusions made in a handful of experimental studies on assurer type are mixed. Evidence by Hodge et al. (2009) does not support the hypothesis that the assurer type affects people's perceptions of the credibility of the information. Pflugrath et al. (2011), however, find to the contrary, showing that financial analysts in Australia, the USA and the UK perceive CSRR to be more credible when the assurer is a professional accountant rather than a sustainability consultant. In China, Shen et al. (2017) find that the assurer type has little impact on a non-professional investor's willingness to invest.

In tandem with the theory of professions, source credibility theory may be able to lend some useful insights into why the persuasiveness of a conclusion differs depending on the profession that issued it (Giffin, 1967). Source credibility theory states that a source is more credible when it holds greater expertise, greater competence and greater trustworthiness (Birnbaum and Stegner, 1979; McGinnies and Ward, 1980; DeZoort et al., 2003; Pornpitakpan, 2006). Less credible information could, for example, be discounted in commercial loan officers loan decisions (Beaulieu, 1994).

By this reckoning, one would expect stakeholders to treat messages of corporate CSR performance from low-credibility sources with skepticism. In this respect, it is not reasonable to assume that a bank director will be familiar with the expertise and reputation of every individual assurance provider. However, according to Schwarzkopf (2007), it is reasonable to believe they will ascribe a level of credibility to a profession. In this regard, accounting firms may have some competitive advantages over other professions. First, auditors are public accountants and research shows that the opinions of public accountants 
MEDAR 28,5

are commonly perceived as being credible. That said, the financial crisis in conjunction with numerous accounting scandals, such as Voltabox and Steinhoff in Germany, Carillion and BHS in the UK, Toshiba in Japan and Linkway Trading owned by the Gupta family in South Africa, has tarnished the reputation of the profession. Furthermore, CSRR assurance differs from traditional financial audits, for example, in that respect that it is less a verification of quantifiable data. As a consequence, it might be questioned whether accountants have greater knowledge than, for example, engineers over the subject matter of CSRR assurance (Farooq and de Villiers, 2019). Therefore, alternate assurance providers may now be deemed more trustworthy and competent, and particularly as CSRR contain more social and environmental information than financial (Wong and Millington, 2014). Notably, these alternate providers are not without their own scandals (e.g. the collapse of a dam in Brazil by Vale, the Volkswagen Dieselgate case or deficient breast implants by Poly Implant Prothèse). Thus, we raise the research question: Does the type of assurance provider impact a bank director's perceptions of a CSRR's credibility?

Prior research frequently finds a positive correlation between accounting firms and the quality of the assurance provided (Moroney et al., 2012; Perego and Kolk, 2012; Ballou et al., 2018; Pflugrath et al., 2011). In particular, in case that the accounting firm is also responsible for assuring the company's financial statements and already has a long-term relationship with the company, it may have a strong understanding of the organization and thus is in a better position to undertake CSRR assurance (Farooq and de Villiers, 2019). Therefore, we have formulated our second hypothesis as follows:

H2. The impact on bank directors' decisions is greater when an accounting firm provides the assurance.

\subsection{Level of assurance}

The objective of CSRR assurance is to provide stakeholders with confidence about a CSRR (Nugent and Simnett, 2007; Cohen and Simnett, 2015). A core element of this confidence is the assurance providers' own stated confidence in their opinion, known as the level of assurance. The level of assurance is the extent to which the assurer feels the information given in a report is correct and, in turn, a reflection of how much trust users should place in the content of a report (Ackers and van Heerden, 2015).

The different types of assurance levels stem from the many national and international audit frameworks that regulate assurance engagements, but the two most common levels are reasonable and limited. For example, ISAE 3000 and ISAE 3410, which govern assurance engagements for financial information and greenhouse gas statements, respectively, both stipulate between reasonable and limited assurance (ISAE 3410.6; Simnett et al., 2009), as does the German Institut der Wirtschaftsprüfer (the Institute of Auditors) in their IDW (2006) PS 821 guidelines under the terms "standard audit" (reasonable assurance) and "review" (limited assurance). The global consulting and standards firm Accountability uses the terms high and moderate assurance level (AA1000AS.3.1.3.).

Both reasonable and limited assurance offer an acceptable level of confidence in the accuracy of the disclosures. However, reasonable assurance is the higher of the two levels and is expressed as an unmodified conclusion in positive form, for example, "that the CSRR is prepared, in all material aspects, in accordance with the legal CSRR provisions" (Braam and Peeters, 2018). This is the typical level of assurance given during a standard financial audit. While still offering an acceptable level of confidence, limited assurance is a conclusion in negative form and so is not as strong as reasonable assurance - for example, "no matters have come to the attention of the assurance provider that causes his/her to believe that the 
CSRR is not prepared, in all material aspects, in accordance with the legal CSRR provisions" (ISAE 3000.71). Implied in these conclusions is that the assurer has undertaken a more thorough audit to reach the stronger and positive reasonable level of assurance (ISAE 3000. A4). From a practical perspective, CSRR often cover multiple subjects associated with mixed levels of assurance - reasonable assurance on some subjects, limited assurance on others and possibly no assurance on others still (Cohen and Simnett, 2015).

The research on assurance levels is extremely limited. As Cohen and Simnett (2015, p. 63) outline: "Research related to the assurance on CSRR is at an early stage of its evolution when compared to decades of research on financial statement audits." We were only able to identify three studies on this topic. In a study of the sustainability reports of the world's largest listed firms, Cuadrado-Bellesteros et al. (2017) find that analysts' forecasts are more accurate when based on reports with a reasonable level of assurance than those with a limited assurance. From a European sample, Fuhrmann et al. (2017) shows that sustainability reports with high assurance levels are significantly and negatively related to bid-ask spread, but other reports are not. While Hodge et al. (2009) did not find a correlation between assurance levels and perceived credibility in their experiments involving Australian MBA students and sustainability report assurance.

We believe that a positively formulated assurance level is likely to be more appealing to stakeholders than a negative one. Additionally, it is reasonable to conjecture that users will place less stock in limited assurance if they know it to be a lower cost, more superficial undertaking. However, what is not clear is whether stakeholders will be able to differentiate between the two levels of assurance. As a result, we pose the research question: Does the level of assurance impact a bank director's perceptions of credibility in a CSRR?

We take the position that bank directors are knowledgeable parties and so will be able to differentiate between reasonable and limited assurance. Further, there is more support in the research for the positive impact of reasonable assurance than not. Therefore, hypothesis three is formulated as follows:

H3. The extent to which bank directors make favorable decisions on the basis of a CSRR is positively linked to the level of assurance provided. Stronger levels of assurance will garner more favorable decisions.

\section{Research method}

3.1 Experiment

3.1.1 Case materials. To test our hypotheses, we conducted an experiment with a $2 \times 2+1$ between-subjects design. The experiment entailed two treatment variables, assurance provider (accounting firm vs non-accounting assurance provider) and assurance level (reasonable vs limited). In addition, there was one control condition with no CSRR assurance. This resulted in five experimental conditions and each participant received just on condition.

To ensure a realistic setting, we selected an actual company and upscaled its financial data by a factor of 1.5. Three public accountants from different Big 4 accounting firms checked the case for realism, which resulted in some minor alterations. The final case materials were then presented to participants as a fictitious company called Engineering Factory AG (EF AG). The materials included brief information on the firm such as its headquarters and subsidiaries, the nature of its business, employees and stock exchange listing on the Prime Standard of the Frankfurt Stock Exchange. This was followed by a more detailed description of EF AG's business situation, income statements, balance sheets 
MEDAR 28,5 and free cash flows for two consecutive years. Participants were then informed that EF AG published a CSRR on its website coupled with information on the auditor, the audit opinion and the audit and non-audit fees paid for the assurance. A translation of the original materials from German into English appears in the Appendix.

3.1.2 Dependent variables. Disclosure of non- financial information is essential for managing change toward a sustainable global economy by combining long-term profitability with social justice and environmental protection and to meet the needs of capital providers, with easy access to information on the impact of businesses on society (European Parliament and Council of the European Union, 2014). Information made available through CSRR allows stakeholders to form opinions and to make informed decisions. CSRR assurance potentially increases the credibility of CSRR and reduces stakeholders' decision risks. Thus, the impact of CSRR assurance on bankers' CSRR reliance and decisions are the main focus of our research interest. Credit granting and investment advice are core decisions of bankers.

First, the participants had to read the case. Then, the experimental task asked the participants to judge their reliance on the CSRR on a seven-point Likert scale (RELY), to quantify the probability that they would grant credit to the company (CREDIT) on a scale from $0 \%$ to $100 \%$, to evaluate the likelihood that they would recommend non-professional investors to buy shares of EF AG on a scale from $0 \%$ to $100 \%$ (ADVICE) and the likelihood that they would invest in shares of the EF AG on a scale from $0 \%$ to $100 \%$ (INVEST). Finally, we asked participants to complete a manipulation check survey and to answer some demographic questions in a post-experiment questionnaire.

3.1.3 Independent variables. CSRR may be motivated by economic thinking (Spence and Gray, 2007) and enhance shareholder value. Michelon and Parbonetti (2010) see them as part of the dialogue between a company and its stakeholders, to provide information on a company's activities that legitimize its behavior, inform and change perceptions and expectations of the stakeholders (Vukic, 2015). Such functions can only be fulfilled if the addressees of CSRR perceive them as credible (Ackers and Eccles, 2015). CSRR assurance potentially increases such credibility (Brown-Liburd and Zamora, 2015). However, CSRR assurance is not mandatory in the German environmental setting. Therefore, a company's management needs to decide whether it voluntarily should demand such assurance (Braam and Peeters, 2018) and a first independent variable relates to assurance provision. The purchase of assurance is only appropriate if it is provided at an adequate quality (Quick and Schmidt, 2018). We use the type of assurance provider as a treatment variable because CSRR assurance is not designated by law to chartered accountants. Thus, clients can choose the assurance provider and this choice may impact the perceptions and decisions of addressees. Moreover, the quality of an assurance service may be significantly affected by the assurance level (Cuadrado-Bellesteros et al., 2017; Boiral et al., 2019), our second treatment variable.

The first of two independent variables was assurance provider type (APROVIDER), manipulated at two levels, namely, Big 4 accounting firm and technical control board. In Germany, technical control boards are frequently engaged as alternates to auditors for assurance. They offer a broad range of services such as product inspection, cyber security and data security or functional safety engineering, but also audits and certifications. Thus, the technical control board is an external non-accounting assurance provider.

The second was level of assurance (ALEVEL), also manipulated at two levels: reasonable assurance and limited assurance. In the case materials that included reasonable assurance, the opinion of the assurance provider read as follows: 
In our opinion, on the basis of the knowledge obtained in the audit, the CSR Report of Engineering Factory AG for the period from 1 January 2018 to 31 December 2018 complies, in all material respects, with the Sections 315b, 315c in conjunction with Sections 289b to 289e HGB.

The wording of the limited assurance opinion read:

Based on the procedures performed, nothing has come to our attention that causes us to believe that the CSR Report of Engineering Factory AG for the period from 1 January 2018 to 31 December 2018 is not prepared, in all material respects, in accordance with the Sections 315b, 315c in conjunction with Sections 289b to 289e HGB.

In addition, we included a control condition where no assurance on the CSRR was provided. Thus, there were five experimental conditions. Table 1 provides an overview of the five and the number of participants per cell.

To improve the quality and validity of our research materials, four international researchers with substantial experience in experimental auditing research were asked to provide feedback. In addition, five bankers participated in pilot tests. Both these exercises led to a number of amendments. The final materials were approved by the Institutional Review Board of the university of one of the authors.

\subsection{Participants}

Prior studies have often used business students as participants, which raises some concerns over external validity as the results are not proven to hold in a real-world setting. We do not believe the decisions chosen for analysis in this research can be proxied by business students. Therefore, we selected bank directors as subjects and German bank directors in particular due to the extremely high relevance of banks to the German economy. The German model is described as a decentralized universal bank-based financial system (Elsas and Krahnen, 2004; Hardie and Howarth, 2009) with three pillars, namely, privately owned banks, banks with government involvement including the regionally focused savings banks and small credit cooperatives (Hackethal, 2004). Universal banks offer a wide range of financial services and provide a significant share of finance through both debt and equity holding. In Germany, bank borrowing is the largest single external source of finance, especially via long-term loans (Hackethal et al., 2005; Deutsche Bundesbank, 2012). In this so-called house-bank model, the relationships between banks and their corporate clients is very close (Behr and Schmidt, 2015). For instance, banks are widely represented on the supervisory boards of companies and often control very large blocks of shareholder voting rights. These voting rights derive from either direct ownership of the shares or from proxy powers as many banks operate a stockbroking service which includes an option for proxy rights management to passive investors as part of the share purchasing service (Franks and

\begin{tabular}{|c|c|c|c|c|}
\hline $\begin{array}{l}\text { Experimental } \\
\text { condition }\end{array}$ & $\begin{array}{c}\text { APROVIDER } \\
\mathrm{AF}=\text { accounting firm; } \mathrm{TCB}=\text { technical control } \\
\text { board }\end{array}$ & $\begin{array}{c}\text { ALEVEL } \\
\text { RA = reasonable } \\
\text { assurance } \\
\text { LA = limited assurance }\end{array}$ & $\begin{array}{l}\text { No. of } \\
\text { participants }\end{array}$ & \\
\hline $\begin{array}{l}1 \\
2 \\
3 \\
4 \\
5\end{array}$ & $\begin{array}{l}- \\
\mathrm{AF} \\
\mathrm{AF} \\
\mathrm{TCB} \\
\mathrm{TCB}\end{array}$ & $\begin{array}{l}- \\
\text { LA } \\
\text { RA } \\
\text { LA } \\
\text { RA }\end{array}$ & $\begin{array}{l}23 \\
24 \\
20 \\
18 \\
24\end{array}$ & $\begin{array}{r}\text { Table 1. } \\
\text { Number of } \\
\text { participants per } \\
\text { experimental } \\
\text { condition }\end{array}$ \\
\hline
\end{tabular}


MEDAR 28,5

844

Mayer, 2001; Becht and Boehmer, 2003). Consequently, banks can often: elect their own managers to corporate boards (Dittmann et al., 2010); handle the majority of new issues of marketable securities, frequently placing them with their own customers; and/or serve as financial intermediaries or investment advisory services to and on behalf of a firm. For all these reasons, banks play a major role in the structure of German corporate governance (Cable, 1985; La Porta et al., 2000; Chirinko and Elston, 2006; Goergen et al., 2008).

We used the BaFin database of banks (Bundesanstalt für Finanzdienstleistungsaufsicht = Federal Financial Supervisory Authority) to identify all registered German banks (1,384), and then manually collated the names of all corresponding bank directors from the banks' websites $(3,827$ as of Spring 2019). Next, we randomly selected one director from each bank and sent them an e-mail broadly introducing the research project and kindly requesting participation through a provided web link. To motivate participation, we offered a lottery with a donation to their charity of choice as the prize, plus an executive summary of the research outcomes (by request). One month later, we sent a reminder.

The result were 109 usable responses which means a response rate of 7.9[1]. To test for non-response bias, we performed $t$-tests for all dependent variables, comparing early respondents to those who responded after we sent the reminder (Oppenheim, 2000) and found no significant differences between the two[2], which indicates there is no non-response bias.

Table 2 provides demographic information on the participants.

On average, the participants had just over 25 years of practical experience in banking $($ YEARS mean $=25.64$, median $=25$, range $=5-48)$. The average number of firms for which

\begin{tabular}{lrrrrrr}
\hline Variable & $\mathrm{N}$ & \multicolumn{1}{c}{ Mean } & \multicolumn{1}{c}{$\mathrm{SD}$} & Min & Max & Median \\
\hline YEARS & 95 & 25.64 & 10.2261 & 5 & 48 & 25 \\
NR_FIRMS & 90 & 985.50 & $2,165.9077$ & 0 & 10,000 & 200 \\
NR_ADV & 89 & $1,353.48$ & $2,284.9632$ & 0 & 10,000 & 500 \\
AGE & 94 & 3.32 & 0.9969 & 1 & 5 & 3 \\
GENDER & 94 & 1.16 & 0.3682 & 1 & 2 & 1 \\
POSITION & 94 & 1.34 & 0.4764 & 1 & 2 & 1 \\
ACC_EXPERT & 94 & 5.77 & 1.0414 & 2 & 7 & 6 \\
AUD_EXPERT & 94 & 4.57 & 1.7007 & 1 & 7 & 5 \\
RISK & 93 & 4.26 & 1.3262 & 2 & 7 & 4 \\
TRUST_REPORT & 94 & 4.82 & 1.1068 & 2 & 7 & 5 \\
TRUST_CSR & 94 & 3.74 & 1.3752 & 1 & 6 & 4 \\
TRUST_BOARD & 93 & 4.82 & 0.8840 & 3 & 6 & 5 \\
TRUST_AUD & 94 & 5.04 & 1.2085 & 1 & 7 & 5 \\
TRUST_TCB & 92 & 3.70 & 1.3566 & 1 & 7 & 4 \\
& & & & & &
\end{tabular}

Notes: YEARS is the number of years the participant works in banking; NR_FIRMS is the number of firms the participant has granted a credit; $N R \_A D V$ is the number of private investors the participant has provided advice; $A G E$ is the age of the participant $(1=<30,2=30-40,3=41-50,4=51-60,5=>60)$; GENDER is the gender of the participant (1= male, $2=$ female); POSITION is the position of the participant within the bank ( 1 = board member, 2 = other); $A C C$ EXPERT is the self-assessed financial accounting knowledge on a seven-point Likert scale; AUD_EXPERT is the self-assessed auditing knowledge on a seven-point Likert scale; RISK is the self-assessed risk attitude on a seven-point Likert scale anchored at 1 = risk-averse and 7 = risk-prone; TRUST_REPORT is the self-assessed trust in annual

Table 2.

Demographic information reports on a seven-point Likert scale; TRUST_CSR is the self-assessed trust in CSRR on a seven-point Likert scale; TRUST_BOARD is the self-assessed trust in directors of companies on a seven-point Likert scale; TRUST_AUD is the self-assessed trust in auditors on a seven-point Likert scale; TRUST_TCB is the self-assessed trust in the technical control board on a seven-point Likert scale 
the subjects had taken part in credit-granting decisions was quite high (NR_FIRMS mean = 985.50), but mean varied considerably (range $=0-10,000$ ). The same was true for investment advice $\left(N R \_A D V\right.$ mean $=1,353.38$, range $\left.=0-10,000\right)$. The exact age of the participants could not be requested for ethical reasons; however, the majority were between 40 and 50 years old. Most were male (mean $=1.16$ ) and sat on the board of directors (mean $=1.34$ ) [3]. Their self-assessed expertise in both financial accounting and auditing tended to be high $\left(\right.$ ACC-EXPERT mean $=5.77 ; A U D \_E X P E R T$ mean $\left.=4.57\right)$ and, on average, they were neither risk-averse nor risk-prone $(R I S K$ mean $=4.26)$. They placed a high level of trust in annual reports, auditors and boards of directors (TRUST_REPORT mean $=4.82$; TRUST_AUD mean = 5.04; TRUST_BOARD mean = 4.82). Conversely, their trust in CSRR and technical control boards was moderate $\left(T R U S T \_C S R\right.$ mean $=3.74 ;$ TRUST_TCB $=$ 3.70).

The experimental materials included three manipulation checks to determine whether the participants had correctly perceived the provision of assurance services. The first check, "Has the CSRR been audited/certified?" was a yes/no question. In total, 30 participants failed to pass this manipulation check and were excluded from further analyzes. Ten participants incorrectly answered the second check, "Who provided assurance on the CSRR of EF AG?" and were also excluded. The third question, "How do you perceive the provided level of assurance on the CSRR?" was designed to control for assurance level perceptions. Answered on a seven-point Likert scale ( $1=$ low; $7=$ high), respondents should have perceived limited assurance as being of lower quality than reasonable assurance. A mean of 3.12 for limited assurance compared to a mean of 4.69 for reasonable assurance $(t=-2.977, p=0.005)$ indicates a successful manipulation.

\section{Results}

As Table 3 shows, the means of all dependent variables concerning the type of assurance provider were higher when an accounting firm provided the assurance. In terms of the assurance level, all means were lower when only limited assurance was provided.

Table 4 shows the means of the dependent variables for the five experimental conditions. Reasonable assurance provided by an accounting firm received the highest mean, while the control group with no assurance had the lowest means. Interestingly, limited assurance provided by an accounting firm had a consistently higher means than a reasonable level of assurance provided by a technical control board.

To examine whether any assurance at all had an impact on the perceptions and decisions of bank directors, and thus to test the first hypothesis, we performed $t$-tests for all four dependent variables by comparing the control group (with no assurance) to a pooled sample of every other response[4]. As reported in Table 5, we found highly significant differences between the two groups, with the control group scoring lower in all dependent variables. This indicates that assurance on CSRR positively affects the decisions of bank directors. In other words, bank directors rely more in the CSRR and are more likely to grant credit,

\begin{tabular}{lrccccccrrr}
\hline \multicolumn{2}{c}{ Variable } & \multicolumn{2}{c}{ RELY } & \multicolumn{2}{c}{ CREDIT } & \multicolumn{2}{c}{ ADVICE } & \multicolumn{2}{c}{ INVEST } & \\
Factor & Level & Mean & SD & Mean (\%) & SD (\%) & Mean (\%) & SD (\%) & Mean (\%) & SD (\%) & \\
\hline \multirow{2}{*}{ APROVIDER } & AF & 5.30 & 1.1706 & 76.0 & 15.19 & 57.4 & 23.67 & 59.4 & 28.00 & Means and standard \\
\multirow{2}{*}{ ALEVEL } & TCB & 4.14 & 1.2069 & 55.0 & 20.35 & 41.3 & 17.92 & 40.9 & 22.81 & deviations of \\
& LA & 4.39 & 1.1962 & 59.9 & 23.30 & 43.2 & 18.51 & 44.7 & 21.45 & dependent variables \\
& RA & 5.12 & 1.3365 & 72.4 & 15.76 & 56.3 & 24.35 & 56.8 & 30.71 & by factor levels \\
\hline
\end{tabular}

Assurance on

\section{CSR reports}

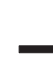


MEDAR 28,5

846

recommend the purchase of shares or make investments in a firm based on an assured CSRR than a non-assured report. $H 1$ is hence confirmed.

Turning to the second and third hypothesis, the results of the ANOVAs appear in Table 6 [5] along with the means, standard deviations and post hoc pair-wise comparison tests (Tukey's HSD)[6]. Table 6, Panel A shows the ANOVA results for the directors' reliance on the CSRR. In support of the $H 2$, assurance provided by an accounting firm had a significant positive impact $(F=10.58$; $p$-value $=0.002) . H 3$ was also supported, meaning

\begin{tabular}{|c|c|c|c|c|c|c|c|c|}
\hline \multirow{2}{*}{$\begin{array}{c}\text { Variable } \\
\text { Experimental condition }\end{array}$} & \multicolumn{2}{|c|}{ RELY } & \multicolumn{2}{|c|}{ CREDIT } & \multicolumn{2}{|c|}{ ADVICE } & \multicolumn{2}{|c|}{ INVEST } \\
\hline & Mean & SD & Mean $(\%)$ & $\mathrm{SD}(\%)$ & Mean $(\%)$ & $\mathrm{SD}(\%)$ & Mean $(\%)$ & $\mathrm{SD}(\%)$ \\
\hline 1 & 2.32 & 1.5653 & 39.0 & 29.70 & 30.5 & 21.39 & 32.9 & 19.21 \\
\hline 2 & 5.00 & 0.7845 & 71.9 & 16.61 & 52.8 & 14.98 & 54.4 & 18.93 \\
\hline 3 & 5.62 & 1.4456 & 80.4 & 12.67 & 62.4 & 30.32 & 64.9 & 35.32 \\
\hline 4 & 3.44 & 1.1304 & 41.3 & 20.15 & 28.2 & 12.82 & 29.6 & 16.18 \\
\hline 5 & 4.62 & 1.0439 & 64.4 & 14.77 & 50.3 & 15.38 & 48.7 & 23.96 \\
\hline
\end{tabular}

\section{Table 5.}

Differences in means of the dependent variables of control vs other experimental

\begin{tabular}{lcccr}
\hline Variable & Mean control & Mean all other & $t$-value & $p$-value \\
\hline RELY & 4.78 & 2.32 & 6.571 & $<0.001$ \\
CREDIT & $66.5 \%$ & $39.0 \%$ & 4.366 & $<0.001$ \\
ADVICE & $50.2 \%$ & $30.5 \%$ & 3.273 & 0.002 \\
INVEST & $51.1 \%$ & $32.9 \%$ & 2.659 & 0.010 \\
\hline
\end{tabular}

conditions

\begin{tabular}{|c|c|c|c|c|}
\hline Panel A & $\begin{array}{c}\text { ANOVA results } \\
\text { Type III sum of squares }\end{array}$ & df & $F$-value & $p$-value \\
\hline Intercept & 106.78 & 1 & 85.23 & $<0.001$ \\
\hline APROVIDER & 13.26 & 1 & 10.58 & 0.002 \\
\hline ALEVEL & 7.29 & 1 & 5.82 & 0.020 \\
\hline APROVIDER $\times$ ALEVEL & 0.92 & 1 & 0.73 & 0.397 \\
\hline $\begin{array}{l}\text { Residuals } \\
N\end{array}$ & $\begin{array}{l}56.38 \\
48\end{array}$ & 45 & & \\
\hline Panel B & & Means & & \\
\hline & & Mean & & \\
\hline TCB LA & & 3.44 & & \\
\hline TCB RA & & 4.62 & & \\
\hline AF LA & & 5.00 & & \\
\hline AF RA & & 5.62 & & \\
\hline Panel C & \multicolumn{4}{|c|}{ post hoc tests (Tukey HSD) } \\
\hline Comparison & \multicolumn{4}{|c|}{$p$-value (two-tailed) } \\
\hline TCB RA vs TCB LA & \multirow{2}{*}{\multicolumn{4}{|c|}{$\begin{array}{l}0.089 \\
0.489\end{array}$}} \\
\hline AF RA vs AF LA & & & & \\
\hline AF RA vs TCB RA & \multicolumn{4}{|c|}{0.119} \\
\hline AF LA vs TCB LA & \multicolumn{4}{|c|}{0.011} \\
\hline
\end{tabular}

Table 6.

Results for the dependent variable RELY
Table 4. dependent variables by experimental conditions

\section{.}


that the directors tended to rely more on the CSRR when the assurance level was reasonable $(F=5.82 ; p$-value $=0.020)$. There was no significant interaction between the two treatment variables $(F=0.73 ; p$-value $=0.397)$.

In Table 6, Panel $\mathrm{C}$ shows the post hoc tests results. Although the means met our expectations, not all tests indicated significant differences. The provision of assurance by an accounting firm only increased the reliance in the CSRR within a limited assurance engagement $(p$-value $=0.011)$. For a reasonable assurance engagement, the mean was 5.62 when an accounting firm provided the assurance and 4.62 in case of assurance provision by the TCB. However, the difference was not significant $(\phi$-value $=0.119)$. Likewise, a reasonable assurance engagement significantly increased such reliance only when the assurance was provided by the TBC $(p$-value $=0.089)$. Conversely, when the assurance was provided by an accounting firm, the mean for a reasonable assurance (5.62) was higher than the mean for limited assurance (5.00). However, the mean difference was insignificant ( $\phi$ value $=0.489$ ).

The second dependent variable is how likely the directors feel they would be to grant credit to EF AG. The ANOVA results are given in Table 7, Panel A. The likelihood of granting credit increased significantly with assurance provided by an accounting firm $(F=$ 20.18; $p$-value $<0.001)$, once again confirming $H 2$. The likelihood also increased significantly with a reasonable level of assurance $(F=11.17$; $p$-value $=0.002)$, supporting $H 3$. Again, there was no significant interaction between the two treatment variables $(F=$ $2.48 ;$-value $=0.122$ )

The post hoc tests in Panel $\mathrm{C}$ were all in line with expectations, with most revealing significant differences. Assurance by an accounting firm significantly increased the likelihood of granting credit at both the reasonable level $(\phi$-value $=0.063)$ and the limited level ( $p$-value $<0.001$ ). Moreover, the provision of reasonable assurance resulted in significantly higher credit-granting likelihood in comparison to the provision of limited assurance when the $\mathrm{TBC}$ provided that assurance $(p$-value $=0.009)$. In case that an

\begin{tabular}{|c|c|c|c|c|c|}
\hline Panel A & $\begin{array}{l}\text { ANOVA results } \\
\text { Type III sum of squares }\end{array}$ & $\mathrm{df}$ & $F$-value & $p$-value & \\
\hline $\begin{array}{l}\text { Intercept } \\
\text { APROVIDER } \\
\text { ALEVEL } \\
\text { APROVIDER } \times \text { ALEVEL } \\
\text { Residuals } \\
N\end{array}$ & $\begin{array}{c}153,76.00 \\
5,104.11 \\
2,825.88 \\
627.08 \\
11,379.87 \\
48\end{array}$ & $\begin{array}{r}1 \\
1 \\
1 \\
1 \\
45\end{array}$ & $\begin{array}{r}60.80 \\
20.18 \\
11.17 \\
2.48\end{array}$ & $\begin{array}{r}<0.001 \\
<0.001 \\
0.002 \\
0.122\end{array}$ & \\
\hline $\begin{array}{l}\text { PanelB } \\
\text { Cell } \\
\text { TCB LA } \\
\text { TCB RA } \\
\text { AF LA } \\
\text { AF RA }\end{array}$ & & $\begin{array}{r}\text { Means } \\
\text { Mean } \\
41.33 \\
64.38 \\
71.86 \\
80.38\end{array}$ & & & \\
\hline $\begin{array}{l}\text { Panel C } \\
\text { Comparison } \\
\text { TCB RA vs TCB LA } \\
\text { AF RA vs AF LA } \\
\text { AF RA vs TCB RA } \\
\text { AF LA vs TCB LA }\end{array}$ & & $\begin{array}{r}\text { ests }(T, \\
\text { de (two- } \\
0.009 \\
0.511 \\
0.063 \\
<0.001\end{array}$ & SSD) & & $\begin{array}{r}\text { Table } 7 . \\
\text { Results for the } \\
\text { dependent variable } \\
\text { CREDIT }\end{array}$ \\
\hline
\end{tabular}


MEDAR 28,5

848

accounting firm provided the assurance the mean for a reasonable assurance was higher (80.38) than the mean for a limited assurance (71.86), but the difference between the two means was insignificant $(\phi$-value $=0.511)$.

The next condition tested was how likely the bank directors felt they would be to recommend a share purchase in EF AG to a non-professional investor based on the CSRR. Table 8, Panel A, shows the ANOVA results. Again, assurance by an accounting firm and a reasonable level of assurance both had a significant positive impact on the recommendation in support of $H 2$ and $H 3$, respectively (accounting firm: $F=8.22 ; p$-value $=0.006$; reasonable assurance $F=6.45 ; p$-value $=0.015)$. There was no significant interaction between the two treatment variables $(F=1.15$; $p$-value $=0.289)$.

In this decision, too, the post hoc tests met our expectations but not all tests indicated significant differences. The provision of assurance by an accounting firm only increased the bank directors' likelihood that they would recommend non-professional investors a purchase of shares of the fictitious company for a limited assurance engagement $(p$-value $=$ 0.031). For a reasonable assurance engagement, the mean was 62.38 when an accounting firm provided the assurance and 50.31 in case of assurance provision by the TCB. However, the difference was not significant ( $p$-value $=0.426$ ). Likewise, a reasonable assurance engagement significantly increased this likelihood only when the assurance was provided by the TBC ( $p$-value $=0.067$ ). Conversely, when the assurance was provided by an accounting firm, the mean for a reasonable assurance (62.38) was higher than the mean for limited assurance (52.79). However, the mean difference was insignificant ( $p$-value $=0.604$ ).

In Table 9, Panel A presents the ANOVA results for the final decision as to whether the directors themselves would invest in EF AG. Unsurprisingly, assurance by an accounting firm had a significant positive impact $(F=5.30$; $p$-value $=0.026)$, confirming $H 2$. However, this time, the assurance level was not of consequence $(F=3.06$; $p$-value $=0.087)$. Therefore, $H 3$ is not supported. Again, there were no significant interactions between the two treatment variables $(F=0.34 ; p$-value $=0.561)$.

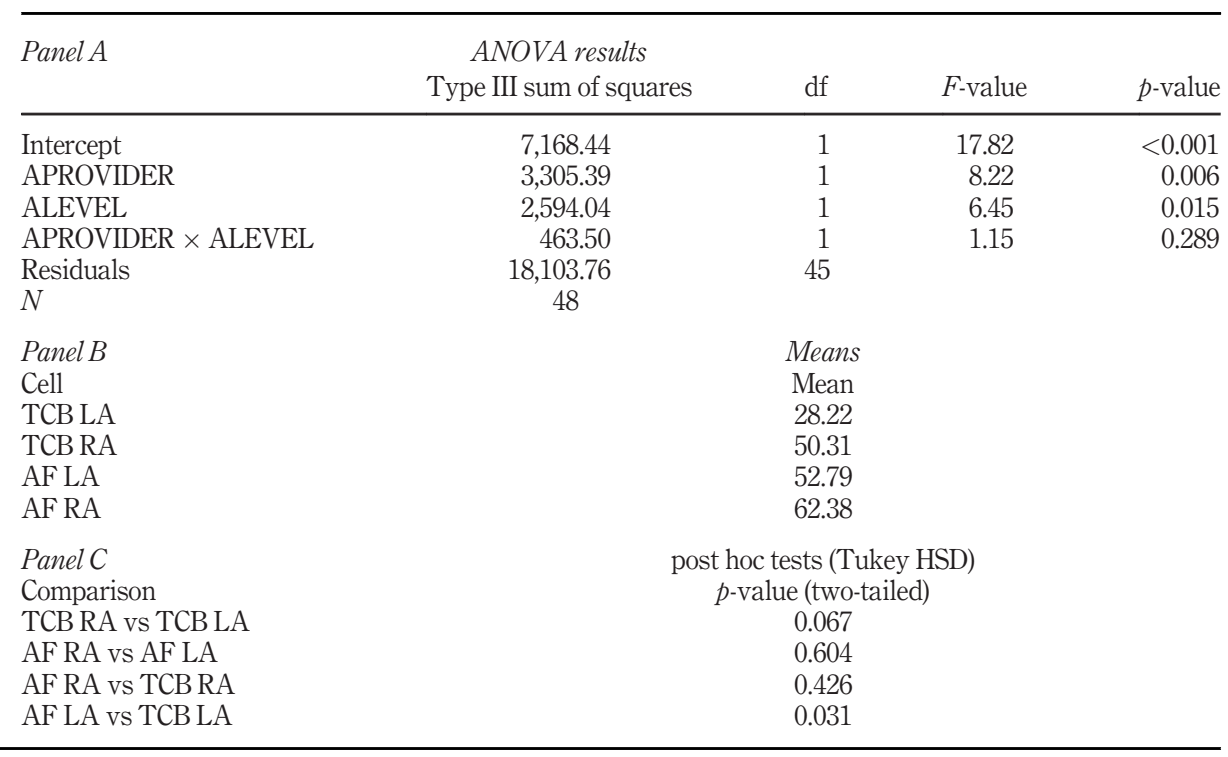

\section{Table 8.}

Results for the dependent variable ADVICE 


\begin{tabular}{|c|c|c|c|c|c|}
\hline Panel A & $\begin{array}{c}\text { ANOVA results } \\
\text { Type III sum of squares }\end{array}$ & df & $F$-value & $p$-value & $\begin{array}{l}\text { Assurance on } \\
\text { CSR reports }\end{array}$ \\
\hline $\begin{array}{l}\text { Intercept } \\
\text { APROVIDER } \\
\text { ALEVEL } \\
\text { APROVIDER } \times \text { ALEVEL } \\
\text { Residuals } \\
N\end{array}$ & $\begin{array}{c}7,861.78 \\
3,369.78 \\
1,947.60 \\
218.38 \\
28,613.13 \\
48\end{array}$ & $\begin{array}{r}1 \\
1 \\
1 \\
1 \\
45\end{array}$ & $\begin{array}{r}12.36 \\
5.30 \\
3.06 \\
0.34\end{array}$ & $\begin{array}{l}0.001 \\
0.026 \\
0.087 \\
0.561\end{array}$ & 849 \\
\hline $\begin{array}{l}\text { Panel B } \\
\text { Cell } \\
\text { TCB LA } \\
\text { TCB RA } \\
\text { AF LA } \\
\text { AF RA }\end{array}$ & & $\begin{array}{r}\text { Means } \\
\text { Mean } \\
29.56 \\
48.69 \\
54.36 \\
64.92\end{array}$ & & & \\
\hline $\begin{array}{l}\text { Panel C } \\
\text { Comparison } \\
\text { TCB RA vs TCB LA } \\
\text { AF RA vs AF LA } \\
\text { AF RA vs TCB RA } \\
\text { AF LA vs TCB LA }\end{array}$ & & $\begin{array}{r}\text { ests }(T \\
\text { de (two } \\
0.311 \\
0.700 \\
0.367 \\
0.113\end{array}$ & SD) & & $\begin{array}{r}\text { Table } 9 . \\
\text { Results for the } \\
\text { dependent variable } \\
\text { INVEST }\end{array}$ \\
\hline
\end{tabular}

The post hoc tests results in Panel $\mathrm{C}$ all lead to insignificant results. However, all means corresponded to our expectations.

Graphs of all the ANOVA results appear in Figure 1.

To ensure that our results were not biased by characteristics of the participants that systematically varied between cells despite random selection, we conducted a ANCOVAs for each dependent variable. First, we calculated the correlations between the dependent variables and the participants' demographic information. Then, we added significantly correlated variables as covariates.

The dependent variable RELY was only significantly correlated with the demographic variable TRUST_CSR (coefficient $=0.445, p$-value $<0.001$ ). Adding the variable TRUST_CSR as a covariate led to results similar to the ANOVA. The significance of the treatment variables was even higher (Table 10, Panel A), and, in addition, there was a significant positive effect of the directors' general reliance on CSRR and their specific reliance on the CSRR in this experiment $(F=6.88$; $p$-value $=0.005)$.

Four demographic variables were significantly correlated to the dependent variable CREDIT: TRUST_CSR (coefficient $=0.258, p$-value $=0.044)$, TRUST_BOARD $($ coefficient $=0.278, p$-value $=0.032), T R U S T \_A U D($ coefficient $=0.286, p$-value $=0.026)$ and TRUST_TCB (coefficient $=0.373, p$-value $=0.004$ ). Using these variables as covariates again confirmed the ANOVA results and increased their significance levels. The covariates themselves were not significant (Table 10, Panel B).

The dependent variable $A D V I C E$ had two significantly correlated demographic variables: POSITION (coefficient $=0.254, p$-value $=0.048)$ and TRUST_CSR $($ coefficient $=$ $0.398, p$-value $=0.001$ ). Adding them as covariates also led to results similar to those from the ANOVA, but with increased significance (Table 10, Panel C). The variable POSITION had no significant impact on the likelihood of granting credit, whereas the variable TRUST_CSR significantly increased it $(F=10.20 ; p$-value $=0.003)$.

The dependent variable INVEST had three significantly correlated demographic variables: $N R \_A D V$ (coefficient $=-0.276 p$-value $\left.=0.040\right), R I S K$ (coefficient $=0.288, p$ - 


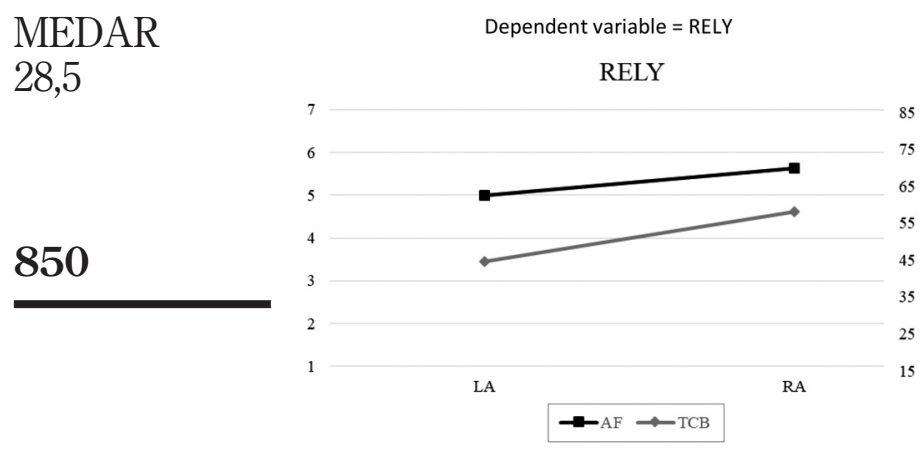

(a)

Dependent variable $=$ ADVICE

ADVICE

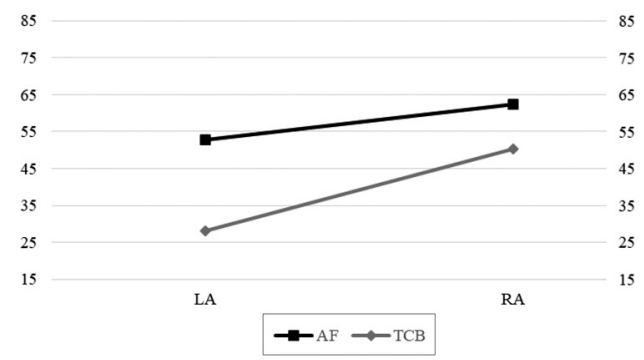

(c)
Dependent variable $=$ CREDIT

CREDIT

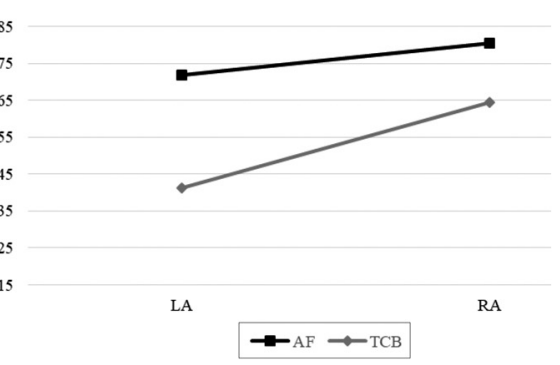

(b)

Dependent variable $=$ INVEST

INVEST

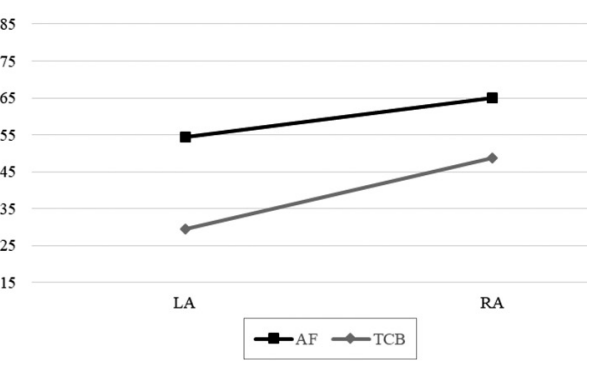

(d)

value $=0.026)$ and TRUST_CSR (coefficient $=0.517 p$-value $=0.000)$. In general, the ANCOVA results were in accordance with the ANOVA results. However, the ANCOVA indicated that the level of assurance is significant where the ANOVA did not (Table 10, Panel D). In addition, all three covariates were significant. More experience in investment consulting $\left(N R \_A D V, F=15.65 ; p\right.$-value $\left.<0.001\right)$ reduced the likelihood that a director would invest in EF AG. Conversely, the directors who were more risk-prone $(F=7.41$; $p$-value $=0.010)$ and had a higher general reliance on $\operatorname{CSRR}(F=4.02 ; p$-value $=0.053)$ were more likely to invest.

In summary, all three hypotheses (first, assurance on CSRR positively impacts bank directors' decisions; second, the impact on bank directors' decisions is greater when an accounting firm provides the assurance; and third, the impact on bank directors' decisions is greater when reasonable assurance is provided) are confirmed. The implication of this is that the purchase of assurance services has a positive effect on bank directors' perceptions and decisions. They favor the provision of such services by accounting firms, and they appreciate a reasonable assurance level. Linking the study's results with expectations derived from legitimacy and signaling theory we show that assured CSRR have a significant positive impact on bank directors' perceptions and decisions. Assurance increases the reliance in CSRR and the likelihood of credit granting, investment advice and personal investment. As disclosed in the hypotheses' section our expectations which derived from the theory of professions and the credit 


\begin{tabular}{|c|c|c|c|c|c|}
\hline \multirow[t]{2}{*}{ Panel A } & \multicolumn{4}{|c|}{ Dependent variable $=R E L Y$} & \multirow{2}{*}{$\begin{array}{r}\text { Assurance on } \\
\text { CSR reports }\end{array}$} \\
\hline & Type III sum of squares & $\mathrm{df}$ & $F$-value & $p$-value & \\
\hline Intercept & 17.08 & 1 & 21.89 & $<0.001$ & \\
\hline APROVIDER & 11.68 & 1 & 14.97 & $<0.001$ & \\
\hline ALEVEL & 8.81 & 1 & 11.29 & 0.002 & \\
\hline APROVIDER $\times$ ALEVEL & 1.26 & 1 & 1.61 & 0.212 & \\
\hline TRUST_CSR & 6.88 & 1 & 8.82 & 0.005 & 851 \\
\hline Residuals & 30.43 & 39 & & & \\
\hline & 44 & & & & \\
\hline \multirow[t]{2}{*}{ Panel B } & \multicolumn{4}{|c|}{ Dependent variable $=$ CREDIT } & \\
\hline & Type III sum of squares & df & $F$ value & $p$-value & \\
\hline Intercept & 32.96 & 1 & 0.19 & 0.669 & \\
\hline APROVIDER & $5,791.09$ & 1 & 32.68 & $<0.001$ & \\
\hline ALEVEL & $2,428.60$ & 1 & 13.71 & 0.001 & \\
\hline APROVIDER $\times$ ALEVEL & 755.38 & 1 & 4.26 & 0.047 & \\
\hline TRUST_CSR & 19.00 & 1 & 0.11 & 0.745 & \\
\hline TRUST_BOARD & 344.54 & 1 & 1.94 & 0.172 & \\
\hline TRUST_AUD & 0.11 & 1 & 0.00 & 0.980 & \\
\hline TRUST_TÜV & 406.07 & 1 & 2.29 & 0.140 & \\
\hline Residuals & $5,846.92$ & 33 & & & \\
\hline$N$ & 41 & & & & \\
\hline \multirow[t]{2}{*}{ Panel C } & \multicolumn{4}{|c|}{ Dependent variable $=$ ADVICE } & \\
\hline & Type III sum of squares & df & $F$ value & $p$-value & \\
\hline Intercept & 427.13 & 1 & 1.72 & 0.197 & \\
\hline APROVIDER & $2,424.42$ & 1 & 9.77 & 0.003 & \\
\hline ALEVEL & $2,254.86$ & 1 & 9.08 & 0.005 & \\
\hline APROVIDER $\times$ ALEVEL & 333.11 & 1 & 1.34 & 0.254 & \\
\hline POSITION & 461.34 & 1 & 1.86 & 0.181 & \\
\hline TRUST_CSR & $2,533.44$ & 1 & 10.20 & 0.003 & \\
\hline Residuals & $9,433.81$ & 38 & & & \\
\hline $\mathrm{N}$ & 44 & & & & \\
\hline \multirow[t]{2}{*}{ Panel D } & \multicolumn{4}{|c|}{ Dependent variable $=$ INVEST } & \\
\hline & Type III sum of squares & df & $F$ value & $p$-value & \\
\hline Intercept & 8.76 & 1 & 0.04 & 0.842 & \\
\hline APROVIDER & $1,419.72$ & 1 & 6.53 & 0.015 & \\
\hline ALEVEL & $1,203.94$ & 1 & 5.53 & 0.024 & \\
\hline APROVIDER $\times$ ALEVEL & 10.54 & 1 & 0.05 & 0.827 & \\
\hline$N R \_A D V$ & $3,404.96$ & 1 & 15.65 & $<0.001$ & \\
\hline RISK & $1,613.11$ & 1 & 7.41 & 0.010 & Table 10. \\
\hline TRUST_CSR & 874.15 & 1 & 4.02 & 0.053 & ANOCVA results for \\
\hline Residuals & $7,615.11$ & 35 & & & all dependent \\
\hline $\mathrm{N}$ & 42 & & & & variables \\
\hline
\end{tabular}

source theory were confirmed. Applying the theoretical lenses to our results mean that bank directors perceive information stemming from accounting firms as more credible than from other assurance providers. The perception differences between accounting and non-accounting assurance providers may also be caused by the fact that they adhere to different standards and apply different methodologies (Farooq and de Villiers, 2019). This effect is in line with prior results as suggested by Ballou et al. (2018), Casey and Grenier (2015) and Cuadrado-Bellesteros et al. (2017), who, however, used very different variables and subject groups than in the study on hand. The 
MEDAR 28,5

assurance level is in most cases relevant for the bank directors' perceptions and decisions. Only for their personal investment decisions, no significant effect has been revealed. Thus, it can be concluded that bank directors are able to identify the difference between reasonable and limited assurance and that the related information is relevant for their decisions.

\section{Conclusion}

With this research, we have attempted to generate some new insights concerning the way users perceive voluntary assurance on CSRR when making decisions. The major contribution of this paper to what Cohen and Simnett (2015, p. 71) describe as a "relatively under-researched but potentially rich and fruitful area for future research" is that we show the influence of CSRR assurance on decisions by bank directors post-implementation of the EU Directive 2014/95. All in all, we contribute to the stream of research engaged in analyzing specific characteristics of assurance, such as Cuadrado-Bellesteros et al. (2017). In this case, those characteristics are the type of assurance provider and the level of assurance provided. This is a crucial area where our research "can help develop a tipping point where it may be to a company's advantage to engage in appropriate CSR behavior and to document this behavior in a report that will receive the rigorous scrutiny of quality assurance providers" (Cohen and Simnett, 2015, p. 72).

Our experiments involved a sample of German bank directors who were asked to make three different decisions based on the CSRR of a fictitious engineering company. The experiments included two manipulations (the type of assurance provider and the level of assurance) and a control group. The three decisions were case evaluations to grant credit, make a share purchase recommendation to their clients and to make their own personal investment in the firm. Our findings suggest that assurance increased the credibility of the information in the minds of the bank directors and that, on the whole, they found CSRR assurance to be decision-useful. This confirms the recent findings obtained by CuadradoBellesteros et al. (2017, p. 1153) who concludes that "sustainability assurance is a valuable tool for improving the accuracy and credibility of sustainability information, thus increasing the analysts' ability to predict future cash flows".

We argue that, with this paper, we have met Abernathy's et al. (2017) research demand by performing an experimental study on the influence of assurance providers that examines whether different CSRR assurance providers carry different levels of credibility. Our results show that when a CSRR was verified by an external assurance provider, the bank directors relied on the reports more. Additionally, they were more willing to grant credits, to advise nonprofessional investors to buy shares in the firm and to invest themselves. Further, the effects were stronger if an accounting firm had provided the assurance. Our analysis also clearly shows that the influence of a reasonable assurance was stronger than that of limited assurance.

The EU Directive 2014/95 did not mandate that an independent assurer verifies the information provided within CSRR but included a Member State option to introduce such mandatory assurance. Some countries, such as France, Italy or Spain made use of this option while others did not. In light of our findings, not only the legislators from those country but also the European legislator might consider mandating the verification of non-financial statements, too. In this perspective, legislators may also consider which assurance providers would be best to engage and what levels of assurance to require. However, regulators should be careful not to stifle competition in the market for CSRR assurance (Farooq and de Villiers, 2019). Moreover, a third-party assurance is a costly and time-consuming process. It is, thus, not surprising that according to the economics-based theory, companies will only use third parties if the expected benefits of external assurance exceeds the costs (Jones and Solomon, 
2010; Lys et al., 2015). CSRR assurance does not only enhance report credibility but also add value by highlighting system and process weaknesses and recommending improvements (Farooq and de Villiers, 2020). Consequently, because CSRR and related assurance are just one component within a company's corporate governance arrangements, the EU legislator should take into account whether alternate elements with a similar function may be more cost-effective than CSRR assurance.

Such as all studies, this work also has limitations. The arguments presented here are limited to the case of the engineering firm used in the experiment and the views held by the bank directors at the time we sent out the questionnaires. It is very possible that the results would vary given a different industry, a different time or by bank directors working in different structural conditions. In addition, our case refers to a specific economic situation of the client and bankers may have formed a perception based on those specific circumstances. We cannot exclude that our participants would react differently, if, for example, the case company was financially distressed. Moreover, our experimental case refers to a given CSRR and it is well possible that bank directors' perceived credibility of assured CSRR varies with report quality. Furthermore, our experimental case assumed assurance provision by a Big 4 accounting firm. As a consequence, we cannot claim that assurance provision by a non-Big 4 accounting firm has a greater impact on bank directors' decisions than assurance provision by an alternate provider. German banks are different from banks in Anglo-Saxon countries insofar as they have much closer relationships to their corporate customers. Therefore, our findings may not apply to countries such as the USA, the UK, Australia or New Zealand. However, countries such as Austria, France (Marchetti and Sabetta, 2010), Italy (De Bonis et al., 2011), Japan (Kutsuna et al., 2007) and Spain (Carrasco et al., 2014) have similarities in their banking systems, and thus, the results of our study are quite likely relevant for such countries, too. Interestingly, the sustainability performances of Germany, Austria, France and Italy are quite similar (Cucchiella et al., 2017). Although the cell sizes analyzed were quite small, which could undermine the reliability of the results (Simmons et al., 2011), having highly knowledgeable subjects, such as bank directors, as opposed to large cell sizes is a more appropriate way of answering our research question: What are bank directors' perceptions concerning the credibility of assured CSRR? Despite the relatively low power of a small sample test, we were able to find highly significant results.

There are a number of lessons to be learned from our findings that present future research opportunities. First of all, given that CSRR assurance is viewed positively, future research could examine the conditions under which companies prefer to have their CSRR assured. In line with Cohen and Simnett (2015, p. 72), it may be worthwhile investigating "whether assurance on CSRR will or will not, be considered a frivolous luxury if a company is in retrenchment mode." More generally, "in this relatively under-researched but potentially rich and fruitful area for future research [...] nearly every research question and research method that has been examined in financial statement audit research can be explored for CSRR assurance," claim Cohen and Simnett (2015, p. 71). This leaves open a vast number of research questions to be explored.

Future work could also investigate whether stakeholders' perceived credibility of CSRR assurance is subject to report quality. In addition, the credibility of CSSR assurance can also be influenced by the type of underlying assurance standards (e.g. ISEA 3000 vs AA1000AS standard; Farooq/de Villiers 2019). This leads to another promising avenue of future research, to investigate whether stakeholders' perceptions and decisions differ according to the applied assurance standard. CSSR assurance engagement differ from narrow to broad in scope and are tailored to reporters' requirements (Farooq and de Villiers, 2020). Future studies could investigate whether such scope variations impact credibility perceptions of stakeholders. 
MEDAR

28,5

\section{4}

\section{Notes}

1. The answers of another 14 participants could not be used, for example, because they did not provide information with regard to all dependent variables. Furthermore, we received many responses from participants explaining why they were not willing to participate in our study, for example, due to a lack of time, the fact that the bank is very specific and does not grant credits to companies or the argument that the bank does not have listed clients. Thus, the response rate is much higher than the participation rate. For many analyzes, $\mathrm{N}$ is smaller than 109, as the questionnaire was not completed in full by all participants.

2. RELY: mean early respondents $=4.0$, mean late respondents $=4.4 ; t=-0.771, p=0.443$; CREDIT: mean early respondents $=59.2 \%$, mean late respondents $=57.5 \% ; t=0.227, p=0.821$; $A D V I C E$ : mean early respondents $=3.78$, mean late respondents $=4.12 ; t=1.303, p=0.195$; CREDIT: mean early respondents $=43.2 \%$, mean late respondents $=49.7 \% ; t=-0.933, p=$ 0.354; INVEST: mean early respondents $=43.8 \%$, mean late respondents $=54.1 \% ; t=-1.344$, $p=0.184$.

3. We exclusively invited directors to participate in the study. However, we assumed that some directors passed the experimental materials to staff members or that they did not arrive at the directors but were treated by staff members. Therefore, we asked for the hierarchical position and the responses confirmed our assumption.

4. The application of $t$-tests requires a normal data distribution and assumes equal variances in the two sub-samples. The assumption of normality was violated; however, Mann-Whitney U-tests confirm our findings.

5. These ANOVAs are based on two broad assumptions: a homogeneous variance and normality. Homogeneous variance was proven by Levene-tests. Normality was not proven for most of the dependent variables according to Shapiro Wilk-tests. However, the ANOVA results are robust as non-parametric Scheirer-Ray-Hare tests lead to similar findings.

6. The post hoc analyzes are based on parametric tests and again the assumption of normality was violated. Therefore, we additionally applied Kruskal-Wallis-tests with Benjamini-Hochberg adjustments, which confirm our original results.

\section{References}

Abbott, A. (1988), The System of the Professions, University of Chicago Press, London.

Abernathy, J., Stefaniak, C., Wilkins, A. and Olson, J. (2017), "Literature review and research opportunities on credibility of corporate social responsibility reporting”, American Journal of Business, Vol. 32 No. 1, pp. 24-41.

Ackers, B. and Eccles, N.S. (2015), "Mandatory corporate social responsibility assurance practices: the case of King III in South Africa”, Accounting, Auditing and Accountability Journal, Vol. 28 No. 4, pp. $515-550$.

Ackers, B. and van Heerden, B. (2015), "Can a conceptual framework for corporate social responsibility (CSR) assurance be developed?”, Corporate Ownership and Control, Vol. 12 No. 4, pp. 8-22.

Ackroyd, S. (2016), "Sociological and organizational theories of professions and professionalism", in Dent, M., Bourgeault., I. L., Denis, J.-L. and Kuhlmann, E. (Eds), The Routledge Companion to the Professions and Professionalism, Routledge, London, pp. 15-30.

Alon, A. and Vidovic, M. (2015), "Sustainability performance and assurance: influence on reputation”, Corporate Reputation Review, Vol. 18 No. 4, pp. 337-352.

Ballou, B., Chen, P.-C., Grenier, J.H. and Heitger, D.L. (2018), "Corporate social responsibility assurance and reporting quality: evidence from restatements", Journal of Accounting and Public Policy, Vol. 37 No. 2, pp. 167-188. 
Beaulieu, P. (1994), "Commercial lenders' use of accounting information in interaction with source credibility", Contemporary Accounting Research, Vol. 10 No. 2, pp. 557-585.

Becht, M. and Boehmer, E. (2003), "Voting control in German corporations", International Review of Law and Economics, Vol. 23 No. 1, pp. 1-29.

Behr, P. and Schmidt, R.H. (2015), "The German banking system: characteristics and challenges", SAFE White Paper No. 32, Frankfurt.

Birkey, R.N., Michelon, G., Patten, D.M. and Sankara, J. (2016), "Does assurance on CSR reporting enhance environmental reputation? An examination in the U”, Accounting Forum, Vol. 40 No. 3, pp. 143-152.

Assurance on

CSR reports

Birnbaum, M.H. and Stegner, S.E. (1979), "Source credibility in social judgment: bias, expertise, and the judge's point of view", Journal of Personality and Social Psychology, Vol. 37 No. 1, pp. 48-74.

Boiral, O. (2013), "Sustainability reports as simulacra? A counter-account of a and a+ GRI reports", Accounting, Auditing and Accountability Journal, Vol. 26 No. 7, pp. 1036-1071.

Boiral, O., Heras-Saizarbitoria, I., BBrotherton, M.-C. and Bernard, J. (2019), "Ethical Issues in the assurance of sustainability reports: perspectives from assurance providers", Journal of Business Ethics, Vol. 159 No. 4, pp. 1111-1125.

Braam, G. and Peeters, R. (2018), "Corporate sustainability performance and assurance on sustainability reports: diffusion of accounting practices in the realm of sustainable development", Corporate Social Responsibility and Environmental Management, Vol. 25 No. 2, pp. 164-181.

Brock, D.M., Leblebici, H. and Muzio, D. (2014), "Understanding professionals and their workplaces: the mission of the journal of professions and organization", Journal of Professions and Organization, Vol. 1 No. 1, pp. 1-15.

Brown-Liburd, H. and Zamora, V.L. (2015), “The role of corporate social responsibility (CSR) assurance in investors' judgments when managerial pay is explicitly tied to CSR performance", Auditing: A Journal of Practice and Theory, Vol. 34 No. 1, pp. 75-96.

Cable, J. (1985), "Capital market information and industrial performance: the role of West German banks", The Economic Journal, Vol. 95 No. 377, pp. 118-132.

Campbell, D., Craven, B. and Shrives, P. (2003), "Voluntary social reporting in three FTSE sectors: a comment on perception and legitimacy", Accounting, Auditing and Accountability Journal, Vol. 16 No. 4, pp. 558-581.

Carrasco, C.A., Peinado, P. and Rodríguez González, C. (2014), "The Spanish financial system and the financial crisis”, Intereconomics, Vol. 49 No. 2, pp. 82-87.

Casey, R.J. and Grenier, J.H. (2015), "Understanding and contributing to the enigma of corporate social responsibility (CSR) assurance in the United States", Auditing: A Journal of Practice and Theory, Vol. 34 No. 1, pp. 97-130.

Cheng, M.M., Green, W.-J. and Ko, J.C.W. (2015), "The impact of strategic relevance and assurance of sustainability indicators on investors' decisions", Auditing: A Journal of Practice and Theory, Vol. 34 No. 1, pp. 131-162.

Cheng, B., Ioannou, I. and Serafeim, G. (2014), "Corporate social responsibility and access to finance", Strategic Management Journal, Vol. 35 No. 1, pp. 1-23.

Chirinko, R.S. and Elston, J.A. (2006), "Finance, control and profitability: the influence of German banks", Journal of Economic Behavior and Organization, Vol. 59 No. 1, pp. 69-88.

Cho, C.H., Michelon, G., Patten, D.M. and Roberts, R.W. (2014), "CSR report assurance in the USA: an empirical investigation of determinants and effects", Sustainability Accounting, Management and Policy Journal, Vol. 5 No. 2, pp. 130-148.

Cohen, J.R. and Simnett, R. (2015), "CSR and assurance services: a research agenda”, Auditing: A Journal of Practice and Theory, Vol. 34 No. 1, pp. 59-74.

Connelly, B.L., Certo, S.T., Ireland, R.D. and Reutzel, C.R. (2011), "Signalling theory: a review and assessment”, Journal of Management, Vol. 37 No. 1, pp. 39-67. 
MEDAR 28,5

Coram, P.J., Monroe, G.S. and Woodliff, D.R. (2009), "The value of assurance on voluntary nonfinancial disclosure: an experimental evaluation”, Auditing: A Journal of Practice and Theory, Vol. 28 No. 1, pp. 137-151.

Cuadrado-Bellesteros, B., Martínez-Ferrero, J. and García-Sánchez, I.M. (2017), "Mitigating information asymmetry through sustainability assurance: the role of accountants and levels of assurance", International Business Review, Vol. 26 No. 6, pp. 1141-1156.

Cucchiella, F., D'Adamo, I., Gastaldi, M., Koh, S.C.L. and Rosa, P. (2017), "A comparison of environmental and energetic performance of European countries: a sustainability index", Renewable and Sustainable Energy Reviews, Vol. 78, pp. 401-413.

Cuganesan, S., Guthrie, J. and Ward, L. (2010), "Examining CSR disclosure strategies within the Australian food and beverage industry", Accounting Forum, Vol. 34 Nos 3/4, pp. 69-183.

De Bonis, R., Pozzolo, A. and Stacchini, M. (2011), "The Italian banking system: facts and interpretations", SSRN Electronic Journal, doi: 10.2139/ssrn.2126074.

Deegan, C. (2002), "Introduction: the legitimising effect of social and environmental disclosures - a theoretical foundation", Accounting, Auditing and Accountability Journal, Vol. 15 No. 3, pp. $282-311$.

Deegan, C. (2019), "Legitimacy theory", Accounting, Auditing and Accountability Journal, doi: 10.1108/ AAAJ-08-2018-3638.

Detzer, D. (2014), “The German financial system and the financial crisis”, Intereconomics, Vol. 49 No. 2, pp. 56-64.

Deutsche Bundesbank (2012), "Die langfristige entwicklung der unternehmensfinanzierung in deutschland - ergebnisse der gesamtwirtschaftlichen finanzierungsrechnung", Monatsberichte Der Deutschen Bundesbank, Vol. 64 No. 1, pp. 13-28.

Deutscher Bundestag (2017), "Gesetz zur stärkung der nichtfinanziellen berichterstattung der unternehmen in ihren lage- und konzernlageberichten", CSR-Richtlinie-Umsetzungsgesetz. Bundesgesetzblatt, Vol. 1 No. 20, pp. 802-814.

DeZoort, F.T., Hermanson, D.R. and Houston, R.W. (2003), “Audit committee member support for proposed audit adjustments: a source credibility perspective", Auditing: A Journal of Practice and Theory, Vol. 22 No. 2, pp. 189-205.

Dhaliwal, D.S., Li, O.Z., Tsang, A. and Yang, Y.G. (2011), "Voluntary nonfinancial disclosure and the cost of equity capital: the initiation of corporate social responsibility reporting", The Accounting Review, Vol. 86 No. 1, pp. 59-100.

Dittmann, I., Maug, E. and Schneider, C. (2010), "Bankers on the boards of German firms: what they do, what they are worth, and why they are (still) there”, Review of Finance, Vol. 14 No. 1, pp. 35-71.

Dumay, J., Frost, G. and Beck, C. (2015), "Material legitimacy: blending organisational and stakeholder concerns through non-financial information disclosures", Journal of Accounting and Organizational Change, Vol. 11 No. 1, pp. 2-23.

Elsas, R. and Krahnen, J.P. (2004), "Universal banks and the relationship with firms", in Krahnen, J.P. and Schmidt, R.H. (Eds), The German Financial System, Oxford University Press, Oxford, pp. 197-232.

European Parliament and Council of the European Union (2014), "Directive 2014/95/EU of the European Parliament and of the council of 22 October 2014 amending Directive 2013/34/EU as regards disclosure of non-financial and diversity information by certain large undertakings and groups", Official Journal of the European Union, L 330/1 -L330/9.

Faisal, F., Tower, G. and Rusmin, R. (2012), "Legitimising corporate sustainability reporting throughout the world", Australasian Accounting, Business and Finance Journal, Vol. 6, pp. 19-34.

Farooq, M.B. and de Villiers, C. (2019), "The shaping of sustainability assurance through the competition between accounting and non-accounting providers", Accounting, Auditing and Accountability Journal, Vol. 32 No. 1, pp. 307-336. 
Farooq, M.B. and de Villiers, C. (2020), "How sustainability assurance engagement scopes are determined, and its impact on capture and credibility enhancements", Accounting, Auditing and Accountability Journal, Vol. 33 No. 2, doi: 10.1108/AAAJ-11-2018-3727.

Fazzini, M. and Dal Maso, L. (2016), "The value relevance of 'assured' environmental disclosure. The Italian experience", Sustainability Accounting, Management and Policy Journal, Vol. 7 No. 2, pp. 225-245.

Fernando, S. and Lawrence, S. (2014), "A theoretical framework for CSR practices: integrating legitimacy theory, stakeholder theory and institutional theory", Journal of Theoretical Accounting Research, Vol. 10, pp. 149-178.

Franks, J. and Mayer, C. (2001), "Ownership and control of German corporations”, Review of Financial Studies, Vol. 14 No. 4, pp. 943-977.

Freidson, E. (1986), Professional Powers: A Study of the Institutionalisation of Formal Knowledge, University of Chicago Press, Chicago.

Freidson, E. (1989), “Theory and the professions”, Indiana Law Journal, Vol. 64 No. 3, pp. 423-432.

Fuhrmann, S., Ott, C., Looks, E. and Guenther, T.W. (2017), "The content of assurance statements for sustainability reports and information asymmetry", Accounting and Business Research, Vol. 47 No. 4, pp. 369-400.

García-Benau, M.A., Sierra-Garcia, L. and Zorio, A. (2013), "Financial crisis impact on sustainability reporting", Management Decision, Vol. 51 No. 7, pp. 1528-1542.

Gietl, S., Göttsche, M., Habisch, A., Roloff, M. and Schauer, M. (2013), "Does CSR reporting destroy firm value? Empirical evidence on GRI-aligned european firms", Zeitschrift Für Umweltpolitik and Umweltrecht, Vol. 36 No. 1, pp. 56-86.

Giffin, K. (1967), "The contribution of studies of source credibility to a theory of interpersonal trust in the communication process", Psychological Bulletin, Vol. 68 No. 2, pp. 104-120.

Gilbert, D.U. and Rasche, A. (2007), "Opportunities and problems of standardized ethics initiatives - a stakeholder theory perspective”, Journal of Business Ethics, Vol. 82 No. 3, pp. 755-773.

Goergen, M., Manjon, M.C. and Renneboog, L. (2008), "Recent developments in German corporate governance", International Review of Law and Economics, Vol. 28 No. 3, pp. 175-193.

Goss, A. and Roberts, G.S. (2011), "The impact of corporate social responsibility on the cost of bank loans", Journal of Banking and Finance, Vol. 35 No. 7, pp. 1794-1810.

Hackethal, A. (2004), "German banks and banking structure", in Krahnen, J.P. and Schmidt, R.H. (Eds), The German Financial System, Oxford University Press, Oxford, pp. 71-105.

Hackethal, A., Schmidt, R.H. and Tyrell, M. (2005), "Banks and German corporate governance: on the way to a capital market-based system? ", Corporate Governance: An International Review, Vol. 13 No. 3, pp. 397-407.

Hardie, I. and Howarth, D. (2009), "Die Krise but not La crise? The financial crisis and the transformation”, JCMS: Journal of Common Market Studies, Vol. 47 No. 5, pp. 1017-1039.

Hodge, K., Subramaniam, N. and Stewart, J. (2009), "Assurance of sustainability reports: impact on report users' confidence and perceptions of information credibility", Australian Accounting Review, Vol. 19 No. 3, pp. 178-194.

Jones, M.J. and Solomon, J.F. (2010), "Social and environmental report assurance: some interview evidence", Accounting Forum, Vol. 34 No. 1, pp. 20-31.

Kolk, A. and Perego, P. (2010), "Determinants of the adoption of sustainability assurance statements: an international investigation”, Business Strategy and the Environment, Vol. 19 No. 3, pp. 182-198.

KPMG (2017), The Road Ahead. The KPMG Survey of Corporate Responsibility Reporting, available at: https://home.kpmg/content/dam/kpmg/campaigns/csr/pdf/CSR_Reporting_2017.pdf

Kutsuna, K., Smith, J.K. and Smith, R.L. (2007), "Banking relationships and access to equity capital markets: evidence form Japan's main bank system”, Journal of Banking and Finance, Vol. 31 No. 2, pp. 335-360. 
MEDAR 28,5

La Porta, R., Sopez-de-Silanes, F., Shleifer, A. and Vishny, R. (2000), "Investor protection and corporate governance", Journal of Financial Economics, Vol. 58 No. 1-2, pp. 3-27.

Larson, M.S. (1977), The Rise of Professionalism, University of CA Press, Berkeley.

Larson, M.S. (1990), "In the matter of expert and professionals, or how impossible it is to leave nothing unsaid", in Torstendhal, R. and Burrage, M. (Eds) The Formation of Professions: Knowledge, State and Strategy, SAGE, London, pp. 24-50.

Lys, T., Naughton, J.P. and Wang, C. (2015), "Signaling through corporate accountability reporting", Journal of Accounting and Economics, Vol. 60 No. 1, pp. 56-72.

McGinnies, E. and Ward, C. (1980), "Better liked than right: trustworthiness and expertise as factors in credibility", Personality and Social Psychology Bulletin, Vol. 6 No. 3, pp. 467-472.

Macdonald, K.M. (1995), The Sociology of the Professions, SAGE Publications, London.

Marchetti, P. and Sabetta, A.J. (2010), "The cooperative banking system in France", in Boscia, V., Carretta, A. and Schwizer, P.H. (Eds), Cooperative Banking in Europe. Case Studies, Palgrave Macmillan, Houndmills, pp. 51-94.

Martínez-Ferrero, J. and García-Sánchez, I.-M. (2017), "Sustainability assurance and cost of capital: does assurance impact on credibility of corporate social responsibility information?", Business Ethics: A European Review, Vol. 26 No. 3, pp. 223-239.

Martínez-Ferrero, J. and García-Sánchez, I.M. (2018), “The level of sustainability assurance: the effects of brand reputation and industry specialisation of assurance providers", Journal of Business Ethics, Vol. 150 No. 4, pp. 971-990.

Michelon, G. and Parbonetti, A. (2010), "The effect of corporate governance on sustainability disclosure", Journal of Management and Governance, Vol. 16 No. 3, pp. 477-509.

Michelon, G., Patten, D.M. and Romi, A.M. (2019), "Creating legitimacy for sustainability assurance practices: evidence from sustainability restatements", European Accounting Review, Vol. 28 No. 2, pp. 395-422.

Moroney, R., Windsor, C. and Aw, Y.T. (2012), "Evidence of assurance enhancing the quality of voluntary environmental disclosure: an empirical analysis", Accounting and Finance, Vol. 52 No. 3, pp. 903-939.

Nugent, M. and Simnett, R. (2007), "Developing an assurance standard for carbon emissions disclosures", Australian Accounting Review, Vol. 17 No. 42, pp. 37-47.

Patten, D. (2019), "Seeking legitimacy", Sustainability Accounting, Management and Policy Journal.

Perego, P. and Kolk, A. (2012), "Multinationals' accountability on sustainability: the evolution of thirdparty assurance of sustainability reports", Journal of Business Ethics, Vol. 110 No. 2, pp. 173-190.

Peters, G.P. and Romi, A.M. (2015), "The association between sustainability governance characteristics and the assurance of corporate sustainability reports", Auditing: A Journal of Practice and Theory, Vol. 34 No. 1, pp. 163-198.

Pflugrath, G., Roebuck, P. and Simnett, R. (2011), "Impact of assurance and assurer's professional affiliation on financial analysts' assessment of credibility of corporate social responsibility information", Auditing: A Journal of Practice and Theory, Vol. 30 No. 3, pp. 239-254.

Pornpitakpan, C. (2006), "The persuasiveness of source credibility: a critical review of five decades' evidence", Journal of Applied Social Psychology, Vol. 34 No. 2, pp. 243-281.

Porter, M.E., §. and Kramer, M.R. (2006), "Strategy and society: the link between competitive advantage and corporate social responsibility", Harvard Business Review, Vol. 84 No. 12, pp. 78-92.

Power, M. (1997), The Audit Society: Rituals of Verification, Oxford University Press, Oxford.

Quick, R. and Schmidt, F. (2018), "Do audit firm rotation, auditor retention, and joint audits matter? An experimental investigation of bank directors' and institutional investors' perceptions", Journal of Accounting Literature, Vol. 41, pp. 1-21.

Reimsbach, D., Hahn, R. and Gürtürk, A. (2018), "Integrated reporting and assurance of sustainability information: an experimental study on professional investors' information processing", European Accounting Review, Vol. 27 No. 3, pp. 559-581. 
Ruhnke, K. and Gabriel, A. (2013), "Determinants of voluntary assurance on sustainability reports: an empirical analysis", Journal of Business Economics, Vol. 83 No. 9, pp. 1063-1091.

Saks, M. (2012), "Defining a profession: the role of knowledge and expertise", Professions and Professionalism, Vol. 2 No. 1, pp. 1-10.

Schwarzkopf, D.L. (2007), “Investors' attitudes toward source credibility”, Managerial Auditing Journal, Vol. 22 No. 1, pp. 18-33.

Shen, H., Wu, H. and Chand, P. (2017), "The impact of corporate social responsibility assurance on investor decisions: Chinese evidence", International Journal of Auditing, Vol. 21 No. 3, pp. 271-287.

Simmons, J.P., Nelson, L.D. and Simonsohn, U. (2011), "False-positive psychology: undisclosed flexibility in data collection and analysis allows presenting anything as significant", Psychological Science, Vol. 22 No. 11, pp. 1359-1366.

Simnett, R., Nugent, M. and Huggins, A.L. (2009), "Developing and international assurance standard on greenhouse gas statements", Accounting Horizons, Vol. 23 No. 4, pp. 347-363.

Simnett, R., Vanstraelen, A. and Chua, W.F. (2009), "Assurance on sustainability reports: an international comparison”, The Accounting Review, Vol. 84 No. 3, pp. 937-967.

Spence, C. and Gray, R. (2007), Social and Environmental Reporting and the Business Case, Certified Accountants Educational Trust, London.

Sullivan, W.M. (2005), Work and Integrity: The Crisis and Promise of Professionalism in America, 2nd ed., Jossey-Bass, San Francisco.

Velte, P. and Stawinoga, M. (2017), "Empirical research on corporate social responsibility assurance (CSRA): a literature review", Journal of Business Economics, Vol. 87 No. 8, pp. 107-1066.

Vukic, N.M. (2015), "Corporate social responsibility reporting: differences among selected EU countries", Business Systems Research Journal, Vol. 6 No. 2, pp. 63-73.

Wong, R. and Millington, A. (2014), "Corporate social disclosures: a user perspective on assurance", Accounting, Auditing and Accountability Journal, Vol. 27 No. 5, pp. 863-887.

\section{Further reading}

Adams, C.A. and Evans, R. (2004), "Accountability, completeness, credibility and the audit expectations gap”, Journal of Corporate Citizenship, Vol. 2004 No. 14, pp. 97-115.

Brown, N. and Deegan, C. (1998), "The public disclosure of environmental disclosure information - a dual test of media agenda setting theory and legitimacy theory", Accounting and Business Research, Vol. 29 No. 1, pp. 21-41.

Camerer, C.F. and Hogarth, R.M. (1999), "The effects of financial incentives in experiments: a review and capitallabor-production framework", Journal of Risk and Uncertainty, Vol. 19 Nos 1/3, pp. 7-42.

Dowling, J. and Pfeffer, J. (1975), "Organizational legitimacy: social values and organizational behavior", The Pacific Sociological Review, Vol. 18 No. 1, pp. 122-136.

Hogner, R.H. (1982), "Corporate social reporting: eight decades of development at US steel”, Research in Corporate Social Performance and Policy, Vol. 4, pp. 243-250.

IDW (2006), "IDW PS 821. Grundsätze ordnungsmäßiger prüfung oder prüferischer durchsicht von berichten im bereich der nachhaltigkeit”, Die Wirtschaftsprüfung, Vol. 59, pp. 854-863.

Patten, D.M. (2002), "The relation between environmental performance and environmental disclosure: a research note", Accounting, Organizations and Society, Vol. 27 No. 8, pp. 763-773.

TÜVRheinland (2019), "Corporate social responsibility (CSR) and nachhaltigkeit. Zertifizierung von CSR- und nachhaltigkeitsberichten", available at: www.tuv.com/content-media-files/master-content/services/ industrial-services/1520-tuv-rheinland-energie-services/tuv-rheinland-csr-nachhaltigkeit-de.pdf

Zorio, A., García-Benau, M.A. and Sierra, L. (2013), "Sustainability development and the quality of assurance report: empirical evidence", Business Strategy and the Environment, Vol. 22 No. 7, pp. 484-500. 


\section{MEDAR Appendix}

28,5

\section{Experimental case}

Case

General. "Engineering Factory AG" is a mechanical engineering company with its headquarters located in Frankfurt, Germany and with 20 subsidiaries around the world. It produces a broad range of machines with a focus on computerized numerical control (CNC) machining centers for diverse use cases. Since 2016, it has produced robotic systems for additional automation in their CNC machining centers. In recent years, "Engineering Factory AG" has been successful in selling its products both nationally and internationally.

"Engineering Factory AG" has 1,086 employees and its current labor agreement will end on February 28, 2020.

Stocks of "Engineering Factory AG" are listed in the Prime Standard of the Frankfurt Stock Exchange.

Business situation. "Engineering Factory AG" increased sales from €591m (2017) to €603m (2018). The net income slightly increased from $€ 110 \mathrm{~m}$ to $€ 115 \mathrm{~m}$. Cost of materials increased by $5 \%$ to $€ 262 \mathrm{~m}$ due to a higher output and increased prices for raw materials. Labor costs increased by $8 \%$ to $€ 108 \mathrm{~m}$ due mainly to an increase in the number of employees. The personnel expenses ratio is usual in the industry.

In comparison to 2017 , balance sheet total has marginally increased by $€ 24 \mathrm{~m}$, i. e. increased to $€ 396 \mathrm{~m}$. The following figures provide further balance sheet information on the structure of assets and capital at the financial year end December 31, 2018 and December 31, 2017:

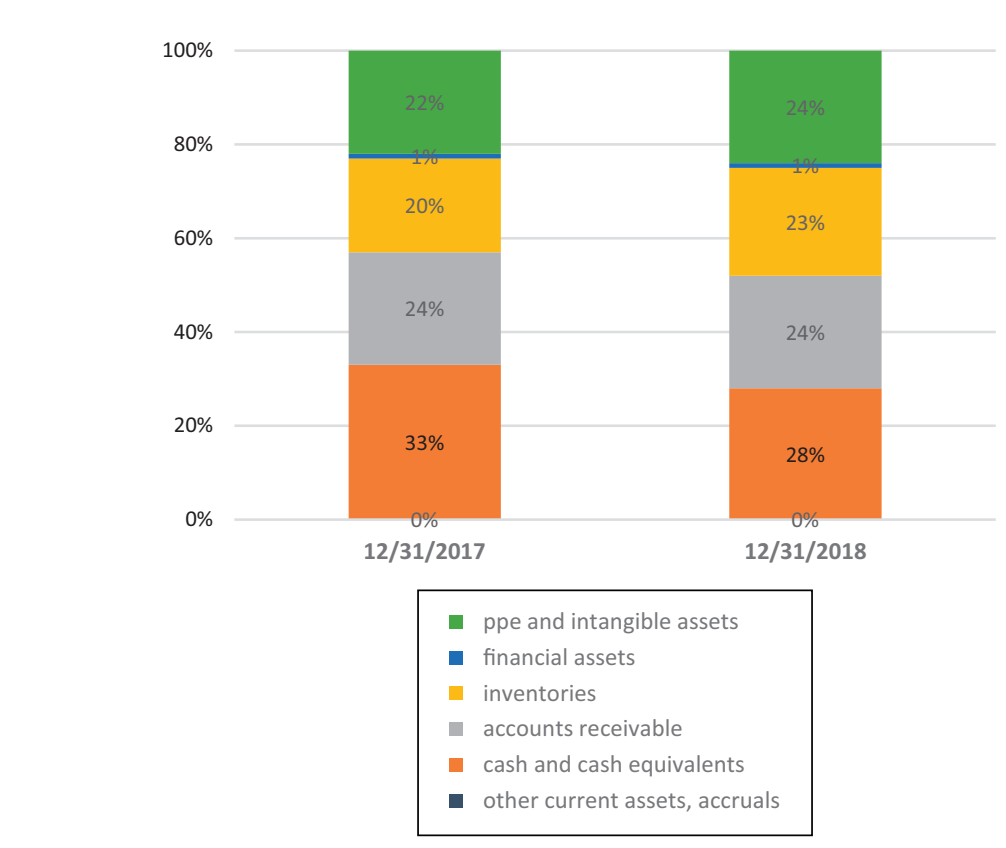

Figure A1.

Structure of assets 


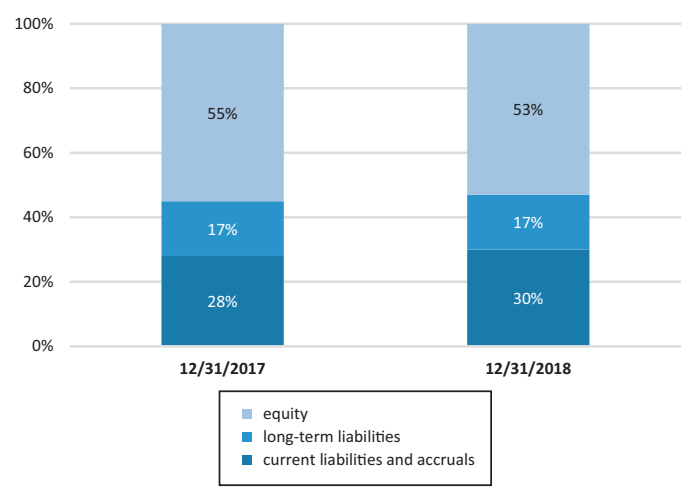

Assurance on CSR reports

861

In 2018, a positive free cash flow of $€ 122 \mathrm{~m}$ was generated (2017: $€ 121 \mathrm{~m})$. The price earnings ratio is 12 (2017: 11).

Corporate governance. The management board of "Engineering Factory AG" consists of three members. These chairpersons receive a fixed basic salary and some fringe benefits such as cars. In addition, the supervisory board determines annually in December a performance-related compensation based on existing contracts.

The supervisory board consists of seven members, two of them represent employees. All members receive a fixed payment at year end and a reimbursement for expenses.

All members of the management and of the supervisory board possess the necessary professional and personal capabilities.

CSR reporting. "Engineering Factory AG" publishes a separate CSR report on its website. Its CSR reporting includes a description of the business model, environmental, social and employee matters, the respect for human rights and anti-corruption and bribery matters. This corresponds to the sector's companies' practices.

Auditor. Since 2012, the accounting firm ABCD is responsible for the statutory audit. ABCD is one of the Big 4 accounting firms which operate on the German audit market. ABCD has always issued an unqualified audit opinion and there has been no disagreement between management and $\mathrm{ABCD}$ over accounting principles, the financial statements and the scope of the audit or the type of audit procedures.

$\mathrm{ABCD}$ performs the statutory audit in accordance with the auditing requirements of the German Commercial Code, the EU regulation on statutory audits of public-interest entities (Regulation (EU) No 537/2014), the auditing standards of the German Institute of Auditors and the International Standards of Auditing.

$\mathrm{ABCD}$ was appointed by the supervisory board of "Engineering Factory AG" and an election by the general meeting.

$\mathrm{ABCD}$ also provides an unqualified opinion for the 2018 audit.

Moreover, $\mathrm{ABCD}$ (the technical control board) provides assurance on EF AG's CSR reporting. It concludes: "Based on the procedures performed, nothing has come to our attention that causes us to believe that the CSRR of EF AG for the period from January 1, 2018, to December 31, 2018, is not prepared, in all material respects, in accordance with the Sections $315 \mathrm{~b}, 315 \mathrm{c}$ in conjunction with Sections 289 b to 289 e HGB". 
MEDAR 28,5

862

Moreover, $\mathrm{ABCD}$ (the technical control board) provides assurance on EF AG's CSR reporting. It concludes: "In our opinion, on the basis of the knowledge obtained in the audit, the CSSR of EF AG for the period from January 1, 2018 to December 31, 2018 complies, in all material respects, with the Sections 315b, 315c in conjunction with Sections $289 \mathrm{~b}$ to $289 \mathrm{e} \mathrm{HGB”.}$

Audit fee. The audit fee paid to ABCD for the statutory audit of the financial statements 2018 is $€ 212,500$. In addition, $\mathrm{ABCD}$ earned $€ 26,250$ for the provision of non-audit services in the same year.

\section{About the author}

Reiner Quick is a Professor of Accounting and Auditing at Darmstadt University of Technology. His research interest focuses on audit quality and auditor independence, the auditor's report, audit markets and audit methodology.

Professor Petra Inwinkl is affiliated with the Technical University of Vienna. She holds doctoral degrees in law from the University of Vienna and in business administration from WU Vienna University of Economics and Business. She has held various positions including visiting appointments at the Jönköping University, Macquarie University, University of North Carolina at Chapel Hill and the University of Vienna. Her research interests cover various aspects of corporate governance including audit committees, auditing of public interested entities, international accounting, corporate mergers and acquisitions and valuations. Petra Inwinkl is the corresponding author and can be contacted at: petra.inwinkl@tuwien.ac.at

For instructions on how to order reprints of this article, please visit our website: 